\title{
Legal Paternalism and the Eclipse of Principle
}

\author{
R. GEORGE WRIGHT*
}

Legal paternalism involves, very roughly, requiring persons to do something for their own good. We often think of debates between legal paternalists and non-paternalists as taking place largely at the level of broad, basic principle. This Article argues, however, that in our culture, disputes over the proper scope of legal paternalism will increasingly focus not on issues of basic principle, but on much more detailed, concrete, particular, contextualized matters. The four major reasons for this eclipse of basic principles bearing upon legal paternalism are herein identified, explored, and illustrated.

INTRODUCTION 195

I. VARIETIES OF LEGAL PATERNALISM AND THE CONFLICTING

MEANINGS OF AUTONOMY

II. KANTIAN FULl AUTONOMY, ITS CONTEMPORARY CRITICS, AND THE ECLIPSE OF AUTONOMY AS A FUNDAMENTAL PRINCIPLE

III. PATERNALISM AND THE INCREASING BLURRINESS OF THE Distinction BETWEEN SELF- AND OTHER-REgARDing ACTIONS

IV. Legal PATERNALISM AND THE PATHOLOGIES OF INDIVIDUAL AND OFFICIAL DECISION-MAKING.

V. Legal PATERNALISM AND THE INCREASING SIGNIFICANCE

OF COMPLEX, DETAILED, CONTEXTUALIZED INQUIRY IN

GENERAL

VI. The ECLIPSE Of PrinciPle IN THE GLuCKSBERG Assisted

* Lawrence A. Jegen Professor of Law, Indiana University Robert H. McKinney School of Law. 


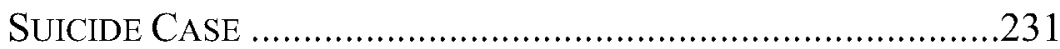

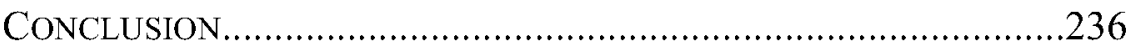

\section{INTRODUCTION}

Issues of legal paternalism arise in many contexts. Such contexts include the regulation of suicide and assisted suicide in particular; ${ }^{1}$ commercial speech $;^{2}$ recreational and therapeutic drug legalization, decriminalization, availability, and screening; ${ }^{3}$ protective helmets

1 See generally infra Section VII.

2 See, e.g., Sorell v. IMS Health, Inc., 564 U.S. 552, 579 (2011); 44 Liquormart, Inc. v. Rhode Island, 517 U.S. 484, 501 (1996) (Stevens, J., for the plurality) ("[W]hen a state entirely prohibits the dissemination of truthful, nonmisleading commercial messages for reasons unrelated to the preservation of a fair bargaining process, there is far less reason to depart from the rigorous review that the First Amendment generally demands."); Riley v. Nat'1 Fed'n of the Blind of N.C., 487 U.S. 781, 790 (1988) (rejecting a paternalistic justification of a regulation of charitable solicitation speech); Retail Dig. Network, LLC v. Appelsmith, 810 F.3d 638, 649 (9th Cir. 2016) (heightened judicial scrutiny for commercial speech regulations as a mechanism to "check raw paternalism"); Dana's RR. Supply v. Attorney General, 807 F.3d 1235, 1251 (11th Cir. 2015) ("Paternalistic efforts at social engineering are anathema to constitutional first principles."); Spirit Airlines, Inc. v. U.S. Dep't of Transp., 687 F.3d 403, 415 (D.C. Cir. 2012) (addressing commercial speech regulations "that seek to keep people in the dark for what the government perceives to be their own good" (quoting Liquormart, 517 U.S. at 503)); Beeman v. Anthem Prescription Mgmt., LLC, 315 P.3d 71, 87 (Cal. 2013) (constitutional skepticism regarding the "paternalistic "assumption that the public will respond "irrationally" to the truth" (quoting Liquormart, 517 U.S. at 503)). More broadly, see Dale Carpenter, The Antipaternalism Principle in the First Amendment, 37 CREIGHTON L. REV. 579, 587-606 (2004).

3 See, e.g., Taylor-Failor v. County of Hawaii, 90 F. Supp. 3d 1095, 1101 (D. Haw. 2015) (paternalistic concern for government employee health); Kirby v. Cty of Fresno, 195 Cal. Rptr. 3d 815, 832-37 (2015) (discussing several issues bearing upon the cultivation of medical marijuana); Commonwealth v. Rodriguez, 37 N.E.3d 611, 614 (Mass. 2015) (addressing some legal ramifications of marijuana decriminalization); Douglas HusAK \& PETER DE MARnEFfe, THE LEGALIZATION OF DRUGS 94 (2005) (debating the merits of decriminalization of drugs akin to heroin); Wayne A. Logan, After the Cheering Stopped: Decriminalization and Legalism's Limits, 24 CORNELL J. L. \& PUB. POL'Y 319, 341-46 (2014) (addressing marijuana decriminalization's legal consequences); Alexandra Natapoff, Misdemeanor Decriminalization, 68 VAND. L. REV. 1055, 1077-1102 (2015) (discussing some politically regressive and inegalitarian dimensions of marijuana decriminalization); Scott Malone, Vermont legislature on track to be first in U.S. to legalize marijuana, REUTERS (Mar. 14, 2016, 4:16 PM), 
for motorcycle riders; ${ }^{4}$ self-representation and the limits of such a right in criminal trials; ${ }^{5}$ workplace regulation and disability $;{ }^{6}$ selection of a conservator or guardian; ${ }^{7}$ smoking in public parks ${ }^{8}$ and smokeless tobacco in specific public venues; ${ }^{9}$ sugar content in some

http://www.reuters.com/article/us-vermont-marijuana-idUSKCN0WG13X (proposal as still prohibiting consumers from growing plants at home, along with imposing a $25 \%$ sales tax).

4 See, e.g., Picou v. Gillum, 874 F.2d 1519, 1521 (11th Cir. 1989) (rejecting the claim that motorcycle helmet laws are purely paternalistic in their motives or justifications); Buhl v. Hannigan, 20 Cal. Rptr. 2d 740, 747-48 (1993) (briefly exploring the constitutionally legitimate scope of legislative paternalism more broadly); Robotham v. State, 488 N.W.2d 533, 540-41 (Neb. 1992) (rejecting the claim of no valid state police power justification, beyond paternalism, for motorcycle helmet requirements); Benning v. State, A.2d 757, 762 (Vt. 1994) (to similar effect); State v. Eckblad, 98 P.3d 1184, 1186 (Wash. 2004) (en banc) (noting the motorcycle helmet requirement cases in the context of a challenge to mandatory automobile seat belts).

5 See, e.g., Indiana v. Edwards, 554 U.S. 164, 176 (2008) (dignity and individual autonomy as underlying the right of criminal trial self-representation, which presumes an appropriate mental capacity); McKaskle v. Wiggins, 465 U.S. 168, 176-77, 178 (1984) (to similar effect); Faretta v. California, 422 U.S. 806, 834-35 (1975) (implicitly contrasting the values of a technically superior but less authentic non-consensual criminal defense); United States v. Frazier-El, 204 F.3d 553, 559 (4th Cir. 2000) (citing Martinez v. Court of Appeal, 528 U.S. 152, 163 (2000)).

6 See, e.g., Chevron USA, Inc. v. Echazabel, 536 U.S. 73, 85 (2002) (the ADA (disability) statute as intended to combat "workplace paternalism"); Class v. Towson Univ., 806 F.3d 236, 256 (4th Cir. 2015) (Wynn, J., concurring in part and dissenting in part) (to similar effect).

7 See, e.g., DeNunzio v. DeNunzio, 128 A.3d 901, 907-11 (Conn. 2016) (discussing the role and limits of explicitly considering the "best interests," as well as any expressed preferences, of the relevant party in appointing a conservator or guardian).

8 See, e.g., NYC C.L.A.S.H., Inc. v. N.Y. State Office of Parks, Recreation, \& Historic Preserv., 125 A.D.3d 105, 109 (N.Y. App. Div. 2014) (discussing the roles of personal autonomy in the context of a public park smoking ban).

9 See, e.g., William Weinbaum, New York bans smokeless tobacco at Yankee Stadium, Citi Field, ESPN (Apr. 6, 2016), http://espn.go.com/mlb/story/_id/151 $49390 \%$. 
kinds of drinks ${ }^{10}$ restaurant calorie disclosures; $;^{11}$ mandated efficiency standards and incentives for light bulbs and other energyconsuming products; ${ }^{12}$ vehicle fuel economy standards; ${ }^{13}$ low-flow lumbing $;{ }^{14}$ the commodification and sale of body parts $;{ }^{15}$ and pros-

10 See, e.g., N.Y. Statewide Coal. of Hispanic Chambers of Commerce v. N.Y.C. Dep't of Health \& Mental Hygiene, 16 N.E.3d 538, 541 (N.Y. 2014) (focusing on fluid ounce limitations on some sugary drinks in some venues); Sugar tax: what does it mean, which drinks will be affected, and will it work?, THE TELEGRAPH (Mar. 17, 2016 7:56 AM), http://www.telegraph.co.uk/food-anddrink/news/sugar-tax-what-does-it-mean-and-who-will-be-affected/ (noting, inter alia, the unpopularity of a sugary drink tax in France and a Norwegian tax on chocolate).

11 See, e.g., One-Year Countdown to Calorie Counts on Menus Starts Next Week, Center For SCIEnce In The Public Interest (Apr. 29, 2016), www.csp inet.org/new/201604292.html (regarding an FDA disclosure requirement affecting many restaurant menus and menu boards).

12 For a brief account, see How the Energy Independence and Security Act of 2007 Affects Light Bulbs, U.S. ENVTL. PROTECTION AGENCY, https:/www.epa.go $\mathrm{v} / \mathrm{cfl} / \mathrm{how}$-energy-independence-and-security-act-2007-affects-light-bulb (last up dated Oct. 15, 2015). See also Tyler Wells Lynch, Your Next Fridge Will Be Mor e Efficient. Here's Why, REVIEWED.COM (Sept. 16, 2014), http:/refrigerators.revi ewed.com/features/everything-you-need-to-know-about-the-new-energy-starfridge-standards. For an introduction to the broader Energy Star consumer and commercial mandate and incentives program, see Certified Products: Energy Savings at Home, ENERGY STAR, https:/www.energystar.gov/products (last visited Apr. 14, 2016).

13 See, e.g., John Lippert \& Jeff Plungis, Auto industry's fuel economy goals are in trouble, AUTOMOTIVE NEws (Jan. 13, 2016, 9:32 AM), http://www.autone ws.com/article/20160113/OEM11/160119838/autoindustrys-fuel-economy-goal s-are-in-trouble. More dramatically, see Alex Hern, Netherlands moots electric car future with petrol and diesel ban by 2025, THE GUARDIAN (Apr. 18, 2016, 10:09 EDT), www.theguardian.com/technology/2016/apr/18/netherlands-parliament-electric-car-petrol-diesel-ban-by-2025.

14 See, e.g., Melody Gutierrez, California drought: Toilets, faucets sold in '16 must be low-flow, SFGATE, www.sfgate.com/bayarea/article/California-drought (last updated April 9, 2015, 10:25 AM).

15 For discussion, see, e.g., MARgaret JANE RADIN, CONTESTED Commodities: The Trouble with Trade in Sex, Children, Body Parts, AND OTHER Things 8, 21 (1996); Stephen Ashley Mortinger, Spleen for Sale: Moore v. Regents of the University of California and the Right to Sell Parts of Your Body, 51 Ohio St. L.J. 499, 500-14 (1990); Radhika Rao, Property, Privacy, and the Human Body, 80 B.U. L. REV. 359, 453-56 (2000). For the suggestion that it not the buying and selling itself that may be objectionable, see JASON BRENNAN \& Peter M. Jaworski, Markets Without Limits: Moral Virtues and COMMERCIAL INTERESTS 206-07 (2016). Markets may well, however, facilitate 
titution in various contexts. ${ }^{16}$

Discussions of the proper role of legal paternalism have long focused on competing fundamental principles, perhaps followed by attempts to apply such fundamental principles in particular contexts and cases. ${ }^{17}$ This Article suggests, however, that we are entering into a period in which debate over fundamental principles regarding legal paternalism will gradually go into eclipse, and attention to various narrower, more detailed problems of practical and contextualized application will increase in prominence. This Article does not endorse or oppose any version of legal paternalism or libertarianism. Rather, its purpose is to question the current practical significance of any broadly principled endorsement of or opposition to legal paternalism.

This Article begins by briefly illustrating some typical understandings of the idea of paternalism, particularly in legal contexts, ${ }^{18}$

and more broadly legitimize the perhaps objectionable further exchange of some good or service. See id. at 206.

16 See, e.g., Peter de Marneffe, Liberalism and Prostitution 4-11 (2009) [hereinafter De Marneffe, Liberalism]; Peter de Marneffe, Vice Laws and Self-Sovereignty, 7 CRIM. L. \& PHIL. 29, 30-31 (2013) [hereinafter de Marneffe, Vice Laws] (seeking to distinguish between decriminalization and legalization); Michelle Madden Dempsey, How to Argue About Prostitution, 6 CRIM. L. \& PHIL. 65, 66-67 (2012) (noting the availability of various forms of both decriminalization and legalization).

17 Early in The Republic, the character of Socrates notes the moral problem of withholding a borrowed weapon from its rightful, but perhaps judgment-impaired, owner. See Plato, The RePublic Book I, 331c (C.D.C. Reeve trans., Hackett Publ'g Co. 1992) ( $\sim 380 \mathrm{BCE})$. Whether a refusal to return the weapon under such circumstances should count as a case of paternalism, or instead as nonpaternalistically protecting the safety of non-consenting third parties, is a recurring conceptual and evidentiary issue. See infra Section IV. More recently, see, e.g., Steven Lee, On the Justification of Paternalism, 7 SOC. THEORY \& PRAC. 193, 193 (1981) ("TT]he justification of paternalism is usually seen in terms of a clash of opposing moral principles.").

18 See infra Section II. Just for the sake of getting the discussion off the ground, we can preliminarily think of paternalism as "interference with a person's liberty of action justified by reasons referring exclusively to the welfare, good, happiness, needs, interests, or values of the person being coerced." Gerald Dworkin, Paternalism, in MILL's ON LIBERTY: CRITICAL ESSAYS 61, 62 (Gerald Dworkin ed., 1997) [hereinafter Dworkin, MILL's ON LIBERTY]. Virtually every element of this definition can be contested, including its ruling out of non-coercive or libertarian paternalism. See generally infra Section II. 
along with closely associated ideas of personal autonomy, ${ }^{19}$ and initially addresses the diminishing significance of matters of basic principle in contemporary discussions of legal paternalism. ${ }^{20}$ The increasing number and variety of distinct understandings of both legal paternalism and autonomy require debate over preliminary issues of definition before any principle can be applied in any context. $^{21}$

Four additional major factors then jointly help to account for the eclipse of basic principle in contemporary discussions of legal paternalism. First, the underlying grounds and logic of the most traditionally crucial form of autonomy have, to many current observers, increasingly seemed suspect. ${ }^{22}$ As belief in this fullest and most crucial sense of autonomy gradually fades, the most important broadly principled grounds for objecting to legal paternalism must eventually fade with it. ${ }^{23}$ Problems of practical implementation, of circumstance, and of particular context then naturally loom larger.

Second, our health insurance, health care systems, and other relevant institutions continue to evolve in broadly social, more intensively collective, less individualized directions. ${ }^{24}$ Against this background, any distinction between self-regarding conduct that affects the actor and other-regarding conduct that affects unconsenting third parties becomes increasingly blurry, shifting, and even arbitrary. ${ }^{25}$ As the self- versus other-regarding conduct distinction continues to blur, the realm of justified paternalism may tend to expand or to narrow, but more crucially, to blur in many contexts, even into unworkability and incoherence. ${ }^{26}$ Where the crucial boundary lines become increasingly blurred, the real significance of any related basic principle is thereby unavoidably reduced. ${ }^{27}$

19 See infra Section II.

20 See infra Sections III, VI.

21 See generally Gerald Dworkin, Paternalism, STAN. ENCYCLOPEDIA OF PHIL. Section 2 http://plato.stanford.edu/entries/paternalism (last updated Jun. 19, 2016) [hereinafter Dworkin, STAN. ENCYCLOPEDIA].

22 See infra Section III.

23 See id.

24 See infra Section IV.

25 See id.

26 See id.

27 See id. 
Third, the proper scope of legal paternalism is increasingly seen as a matter not so much of basic principle, or the clash of opposing basic principles, but of the accumulating evidence and significance of cognitive and other biases, fallacies, pathologies, and systematic irrationalities in decision making. ${ }^{28}$ Such evidence of systematic bias applies not merely to the decision making of generally competent adult decision makers in their personal capacity, but in some forms to government officials and government bodies in a position to adopt, implement, or reject legally paternalistic policies. ${ }^{29}$ The case for legal paternalism thus increasingly depends not on broad principle, but on contextualized comparisons of degrees and forms of various personal and institutional biases and irrationalities. ${ }^{30}$

Fourth, and more broadly, the number, variety, and significance of conceptual, statistical, and evidentiary complications has increased the frequency with which the cases for and against legal paternalism turn not on basic principles, but on just such complex, particularized, technical considerations. ${ }^{31}$ Human intentions, competencies, and values are complex matters, as are the various actual results of many anti-paternalistic policies. ${ }^{32}$ Such complications may often be difficult to work through in advance. But we cannot responsibly resolve today's questions of legal paternalism primarily by appeal to any purported basic principles, while downplaying crucially relevant, if also murkier and more arid, technical complications.

The force of all of these considerations is then illustrated below in a controversial subject matter area one might think most likely to be governed by disputes over basic principle: that of assisted suicide and related emerging statutory and case law. ${ }^{33}$ Even in the controversial assisted suicide context, however, it turns out that the debates decreasingly reflect conflicting basic principles, and increasingly reflect the narrower subtleties, complications, and uncertainties inherent in the various relevant technical issues. ${ }^{34}$

\footnotetext{
28 See infra Section V.

29 See id.

30 See id.

31 See infra Section VI.

32 See id.

33 See infra Section VII.

34 See generally id.
} 


\section{VARIETIES OF LEGAL PATERNALISM AND THE CONFLICTING MEANINGS OF AUTONOMY}

The ideas of paternalism in general, and of paternalism in the legal realm in particular, are notoriously difficult to pin down. ${ }^{35}$ It has been said that "there are as many competing conceptions of paternalism as there are authors . . ." $" 36$ This Article will therefore not commit to any specific definition of paternalism, or of legal paternalism in particular, to the exclusion of other mainstream definitions. A merely general understanding of the concept of paternalism will instead allow for more comprehensive conclusions. A sufficient sense of the idea of paternalism, as well as of some of the important conceptual conflicts, can be drawn from a brief survey of some prominent attempts at a definition of paternalism.

One recent survey of definitions of paternalism, for example, finds three more or less standard components. ${ }^{37}$ These three components are said to involve, respectively, interference with individual freedom, an intention to promote the good of the individual interfered with, and the absence of consent by the person whose freedom is to be interfered with. ${ }^{38}$ These may initially seem to be uncontroversial considerations. But it is not clear, for example, that putting a bequest in a trust, with paternalistic restrictions ${ }^{39}$ or paternalistically hiding one's own potentially dangerous prescription drug ${ }^{40}$ interferes with the freedom or autonomy of the person who is being treated paternalistically.

35 David J. Garren, Paternalism, Part I, 47 PHIL. Books 334, 340 (2006) [hereinafter Paternalism, Part I]

36 Id.; see also David J. Garren, Paternalism, Part II, 48 PHIL. Books 50, 52 (2007) [hereinafter Paternalism, Part II].

37 See Julian LeGrand \& Bill New, Government Paternalism: Nanny STATE OR HELPFUL FRIEND? 2 (2015).

38 See id.

39 See David Enoch, What's Wrong with Paternalism: Autonomy, Belief, and Action, 136 PRoc. ARISTOTELIAN SOC'Y 21, 22 (2016) (discussing related paternalistic behavior that does not involve intrusion on an individual's autonomy).

40 See Gerald Dworkin, Defining Paternalism, in PATERnAlism: TheOry AND PRACTICE 25, 27 (Christian Coons \& Michael Weber eds., 2013) [hereinafter Dworkin, Defining Paternalism]. The linkages between paternalism and autonomy, in one sense or another, are explored infra Section II. More broadly, it has been argued that "[p]aternalism need not involve coercion, lying, deception or the clear infraction of moral rules." David Archard, For Our Own Good, 72 Australasian J. PHIL. 283, 289 (1994). 
As well, some paternalistic laws, as in the case of prohibiting the commercial manufacture of recreational alcohol, are clearly intended to benefit not the regulated would-be manufacturer, but the eventual consumer of alcohol. ${ }^{41}$ There are also cases in which the affected party welcomes and consents to a paternalistic legal regulation, perhaps for fear that its current will to follow its own most fundamental goals would otherwise weaken over time. ${ }^{42}$

One of the leading writers in this area, Professor Gerald Dworkin, defines paternalism as the "interference of a state or an individual with another person, against their will, and defended or motivated by a claim that the person interfered with will be better off or protected from harm." ${ }^{43}$ For our purposes, we again need not object to this or any other reasonable formulation, but Dworkin's formulation raises new and additional controversies. ${ }^{44}$

Among such controversies is whether to define paternalism in normatively unattractive or more neutral terms. ${ }^{45}$ Should we think negatively of paternalism merely by definition? ${ }^{46}$ All else equal, it would seem, "interference" 47 with persons, or "usurpation" $" 48$ of their

41 See Dworkin, STAN. ENCYCLOPEDIA, supra note 21, at Section 2.4. For discussion, see Steven Lee, On the Justification of Paternalism, 7 SOC. THEORY \& PRAC. 193, 194 (1981).

42 See Dworkin, MiLL's On LiBERTY, supra note 18, at 75. For related discussion, see generally Dennis J. Baker, The Moral Limits of Consent as a Defense in the Criminal Law, 12 NEw CRIM. L. REV. 93 (2009). For a prohibition on a challenge to a duel, see Ward v. Commonwealth, 116 S.W. 786, 786-87 (Ky. 1909).

43 Dworkin, Stan. ENCYClOPEDIA, supra note 21. For discussion of similar assumptions, see Rosemary Carter, Justifying Paternalism, 7 CAN. J. PHIL. 133, 133 (1977) ("[A] paternalistic act apparently violates a subject's right to non-interference....").

44 See generally Dworkin, STAN. ENCYClOPEDIA, supra note 21, at Section 2 .

45 See Emma C. Bullock, A Normatively Neutral Definition of Paternalism, 65 PHIL. Q. 1, 1-2 (2015).

46 See id. at 3 (noting that some definitions of paternalism tend to imply that it is morally wrong).

47 See Dworkin, StAn. EnCYClopedia, supra note 21.

48 See David Archard, Paternalism Defined, 50 ANALYsis 36, 36 (1990) ("Paternalism is essentially the usurpation of one person's choice of their own good by another person."). See also Bernard Gert \& Charles M. Culver, The Justification of Paternalism, 89 ETHICS 199, 199 (1979) [hereinafter Gert \& Culver, The 
rights, liberties, and authority, should be avoided. But there may be costs to making all paternalism at least prima facie wrong merely by definition. ${ }^{49}$ So there have been attempts to define paternalism in normatively more neutral terms. ${ }^{50}$

More substantively, it is again far from clear that all paternalism occurs against the will ${ }^{51}$ of the person treated paternalistically. Some cases of paternalism seem instead to take place not contrary to the person's will, but regardless of that will, which may not yet have been formed, may have been manipulated, or may coincidentally happen to be compatible with the paternalistic constraint that would have been imposed. ${ }^{52}$ An otherwise paternalistic act may not lose its paternalistic quality merely because the person being treated paternalistically has not yet made up her mind on the matter at hand, or even happens, perhaps unknown to the party imposing the paternalistic judgment, to coincidentally agree with what she would in any case be required to do. ${ }^{53}$ And then, even if we can settle upon a basic definition of paternalism, or of legal paternalism in particular, ${ }^{54}$ we

Justification of Paternalism] (paternalism as involving the violation of a moral rule).

49 See Bullock, supra note 45 , at 3-5.

50 See id. at 5.

51 Richard J. Arneson, Nudge and Shove, 41 SOC. THEORY \& PRAC. 668,669 (2015) ("[P]aternalism is [a] restriction of an individual's liberty or [a] manipulation of his choice-making, against that individual's will, motivated by the aim of benefiting the individual."); see also Dworkin, STAN. ENCYCLOPEDIA, supra note 21 , at Section 2 . The point of paternalistically manipulating someone, however, may be to avoid or prevent any conflicts with that person's will. See Arneson, supra, at 671. A government may be unaware of the regulated party's will, or no relevant will may yet have been developed. See, e.g., Daniel Groll, Paternalism, Respect, and the Will, 122 ETHICS 692, 698-99 (2012) (identifying other instances where the paternalizer acts without knowledge of individual's will or where the individual has "no will"). Professor Dworkin, it should be noted, also refers to regulatory actions taken merely "without the consent" of the person being treated paternalistically. See Dworkin, STAN. ENCYCLOPEDIA, supra note 21, at Section 2 .

52 Gert \& Culver, The Justification of Paternalism, supra note 48, at 199 (the paternalistic act as undertaken "independently" of any possible past, present, or future consent by the party being treated paternalistically); see also, e.g., Groll, supra note 51, at 698 .

53 Professor Groll refers to this as the "Accidental Concordance" problem. See Groll, supra note 51, at 698.

54 Another leading theorist, Professor Joel Feinberg, suggests that legal paternalism "justifies state coercion to protect individuals from self-inflicted harm, 
then face an expanding array of conceptual problems and complications.

First among such conceptual complications, we must ask whether paternalism must be targeted at steering someone's behavior-at that person doing or not doing something-or whether paternalism can be aimed merely at promoting someone's desired state of mind or belief. ${ }^{55}$ Can there be, for example, genuinely paternalistic government manipulation merely of attitudes or beliefs, and not of anyone's behavior?

Second, we must ask whether paternalism is more a matter of the intent of the person acting paternalistically, or instead of some effect on the person being treated paternalistically. ${ }^{56} \mathrm{~A}$ serious complication for legal paternalism in particular is that legislating bodies may have no ascertainable single intent in imposing a rule. ${ }^{57}$ Intent can be multiple, vague, unascertainable, or even self-contradictory. ${ }^{58}$ To the extent that we cannot determine a multi-member legislative body's distinct primary intent, the existence of any intent necessary for legal paternalism will be unclear. ${ }^{59}$

Third, we must ask whether a government in particular could treat the public paternalistically, and perhaps disrespectfully, even in the course of addressing the public solely with unthreatening and

or in its extreme version, to guide them, whether they like it or not, toward their own good." Joel Feinberg, Legal Paternalism, 1 CAN. J. PHIL. 105, 105 (1971) [hereinafter Feinberg, Legal Paternalism]. Professor Feinberg thus assumes, controversially, that legal paternalism, if not paternalism more generally, must involve coercion, thereby excluding a range of state nudges, incentives, mild inducements, and publicity campaigns insofar as they fall short of coercion. See id. We here set aside any problems in distinguishing avoiding harms and promoting one's good.

55 See Bernard Gert \& Charles M. Culver, Paternalistic Behavior, 6 PHIL. \& PUB. AFF. 45, 46-47 (1976) (discussing arguably paternalistic lies to dying patients and to others whose behavior is not likely to be affected either way).

56 See Paternalism, Part I, supra note 35, at 335 (noting the murkiness of the distinction).

57 See Frank H. Easterbrook, Text, History, and Structure in Statutory Interpretation, 17 HARV. J. L. \& PUB. POL'Y 61, 68 (1994); see also Nicolas Cornell, A Third Theory of Paternalism, 113 MicH. L. REV. 1295, 1313 (2015) ("It is . . notoriously difficult to ascribe a single intention to a law or other government action.").

58 See generally Easterbrook, supra note 57, at 68-70.

59 See Cornell, supra note 57, at 1313. 
purely rational arguments. ${ }^{60}$ We might well think of rational argumentation as the very opposite of paternalism. ${ }^{61}$ But, could rational argumentation ever take on a paternalistic character? ${ }^{62}$ Consider, for example, a government's tedious, unrelenting, time-and-attentionconsuming, and perhaps distracting campaign for some behavioral change, conducted in rational but demeaning and patronizing logical steps and language. ${ }^{63}$

Fourth, we must ask about the many cases in which the effects of the policy or rule in question are apparently mixed, in the sense that they are to some degree paternalistic, and to some degree nonpaternalistic. ${ }^{64}$ In a typical such case, a legal prohibition may be intended to somehow benefit both the person being treated paternalistically and, to one degree or another, other non-consenting persons affected by the conduct of the party being treated paternalistically. ${ }^{65}$ We shall see below ${ }^{66}$ that even if the classic distinction between selfregarding actions and other-regarding actions, however subtly qualified or interpreted, was ever useful, under our current regulatory circumstances, the distinction is now typically useless.

Fifth, we must ask whether any viable distinction can be drawn between paternalism that affects or is intended to affect the ends, goals, values, and priorities held by the person being treated paternalistically, and paternalism that affects - entirely or primarily - the means chosen by that person in pursuing their ends, goals, values, and priorities. ${ }^{67}$ To simplify a bit, can a distinction be maintained between paternalism toward a person's ends and paternalism toward that person's means? ${ }^{68}$

60 See George Tsai, Rational Persuasion as Paternalism, 42 PHIL. \& PUB. AFF. 78, 79 (2014).

61 See Danny Scoccia, The Right to Autonomy and the Justification of Hard Paternalism, in PATERnalism: Theory And Practice 74, 76 (Christian Coons \& Michael Weber eds., 2013) [hereinafter Scoccia, The Right to Autonomy].

62 See generally Tsai, supra note 60, at 79 (introducing his argument that rational persuasion can be paternalistic).

63 See generally Tsai, supra note 60, at 78-79.

64 See, e.g., Dworkin, STAN. EnCyClOPEDIA, supra note 21, at Section 2.4 (discussing "pure" and "impure" paternalism).

65 See id.

66 See infra Section IV.

67 See Dworkin, STAN. ENCYCLOPEDIA, supra note 21, at Sections 2.3-2.4.

68 See, e.g., David Birks, Moral Status and the Wrongness of Paternalism, 40 SOC. THEORY \& PRAC. 483, 487 (2014). For further elaboration, see infra Section 
Sixth and finally, we must consider the murky and evolving relationships between paternalism on the one hand and various forms of autonomy on the other ${ }^{69}$ It is often assumed that some form of autonomy, and the value of autonomy, are central to an understanding of paternalism and its permissible role. ${ }^{70}$ Paternalism is often assumed to limit autonomy. ${ }^{71}$ It might well be that paternalism can restrict autonomy in one respect while increasing it in another respect. ${ }^{72}$ Often, though, it is said that paternalism is wrong when it violates or interferes with the autonomy of the person being treated paternalistically. ${ }^{73}$

Discussions of paternalism, taken collectively, thus involve more than one distinct sense of the idea of autonomy. ${ }^{74}$ Our notions of autonomy have evolved over time. ${ }^{75}$ Crucially, for our purposes the particular sense of the idea of autonomy at stake in any discussion of paternalism often partially determines the nature, content, and outcome of that discussion. ${ }^{76}$

VI. An additional, equally murky distinction is sometimes attempted between paternalism that affects the welfare, well-being, or happiness of the person being treated paternalistically, and paternalism that affects only the moral status or moral character of that person. See Dworkin, supra note 21, at Section 2.5. We also mainly set aside issues of so-called self-paternalism and voluntary precommitment. See, e.g., Jon Elster, Ulysses and THE Sirens: STUdIES IN RATIONALITY AND IRRATIONALITY 37-47 (1984) [hereinafter ULYSSES AND THE SiRENS]; JON Elster, UlysSES UnBOUND: STUDIES IN RATIONALITY, PRECOMMITMENT, AND CONSTRAINTS 4 (2000) [hereinafter UlysSES UNBOUND].

69 See Enoch, supra note 39, at 46.

70 See id. at 47 ("[W] can make progress on the discussion of paternalism ... by better understanding the value of autonomy and its related constraints").

71 See, e.g., Dworkin, STAN. ENCYCLOPEDIA, supra note 21, at 2 ("[Paternalism] involves some kind of limitation on the freedom or autonomy of some agent....").

72 See infra Section VI.

73 See Birks, supra note 68, at 483; see also Danny Scoccia, In Defense of Hard Paternalism, 27 L. \& PHIL. 351, 351, 351 n.1 (2008) [hereinafter In Defense of Hard Paternalism] (listing opponents of autonomy-violating paternalism).

74 See, e.g., Birks, supra note 68, at 484, 484 n.3 (highlighting two kinds of autonomy objections to paternalism and stating that there are "numerous accounts" of autonomy that may be considered in cases of paternalism).

75 See generally John Christman, Autonomy in Moral and Political Philosophy, The Stan. Encyclopedia of Phil. (Mar. 21, 2015), http://plato.stanford. edu/archives/spr2015/entries/autonomgy-moral.

76 See Birks, supra note 68, at 484 n.3. 
In the past, discussions of paternalism and of its proper role have tended to focus on matters of basic principle only when autonomyin what we will below call the fullest sense-is at stake. ${ }^{77}$ When autonomy in a more modest sense is the only form of autonomy thought to be at stake in a given context, discussions of autonomy's proper role typically then focus less on issues of basic principle, and more on matters such as detailed empirical evidence, subtle conceptual analysis, and complex calculations and balancing. ${ }^{78}$ Our thesis in this regard is that autonomy in the fullest sense is gradually losing its credibility and appeal with today's theorists and decision makers, leaving only more modest, less ambitious forms of autonomy in play. This tendency means that discussions of paternalism will increasingly focus on matters of detailed, contextualized, and particularized investigation, rather than appeal to basic principles.

Very roughly, autonomy in the fullest, most ambitious sense focuses on the idea of a will that is capable of genuine agency. ${ }^{79}$ Such a will is capable of being moved by apparently good and bad reasons, including principles. ${ }^{80}$ Such a will would crucially differ from a will that is instead moved by any combination of internal or external physical causes, including random physical events of the sort investigated by the sciences. ${ }^{81} \mathrm{~A}$ will that reflects merely some combination of randomness, current or past bodily or physical circumstances, and any set of biological or other physical laws, would thus not qualify as autonomous in the fullest sense. ${ }^{82}$

Even at this point, we can begin to sense why autonomy in the fullest sense might be more closely linked to basic principles, to fundamental values, and to the idea of inviolability than autonomy in a lesser sense. Autonomy in the fullest sense is historically linked to writers such as Immanuel Kant, ${ }^{83}$ who, not surprisingly, emphasizes the role of principle in discussions of paternalism. ${ }^{84}$ Autonomy in a

\footnotetext{
77 See infra Section III.

78 See Christman, supra note 75.

79 See generally Stephen Darwall, The Value of Autonomy and Autonomy of the Will, 116 ETHICS 263, 281-82 (2006).

80 See id.

81 See id.

82 See id.

83 See infra Section III.

84 This is not to suggest that Kant ignores particular circumstance and context in making moral judgments.
} 
lesser sense may, in the end, reduce to something like the absence of some disfavored set of socially-imposed or psychological obstacles to attaining what we desire. Autonomy in a lesser sense tends to be more broadly political than metaphysical. The value of autonomy in such a lesser sense may, at bottom, reflect merely something like a preference for some particular causes of our decisions, and for non-frustration over the experience of frustration.

Not surprisingly, then, the nature and status of autonomy has of late been widely discussed. ${ }^{85}$ Autonomy in a lesser, mostly social or political sense, akin to valued social and political freedom, is doubt-

85 See, e.g., ANDrew Sneddon, AUtONOMy 122-23 (2013) (ebook) (distinguishing between "autonomy of choice" and "autonomy of person"); Gerald Dworkin, The Concept of Autonomy, in THE INNER CITADEL: EsSAYs ON Individual Autonomy 54, 61 (John Christman ed., 1989) [hereinafter Concept of Autonomy] (autonomy as authenticity plus procedural independence in decision-making); Gerald Dworkin, The Theory and Practice of Autonomy 108 (1988) [hereinafter DWORKIN, THEORY AND PRACTICE of AUtONOMY ] (defining autonomy as "the capacity to reflect upon one's motivational structure and to make changes in that structure."); Joel Feinberg, Autonomy, in THE INNER CITADEL: ESSAYS ON INDIVIDUAL AUTONOMY, supra, at 27, 32 [hereinafter Feinberg, Autonomy] ("To the degree to which a person is autonomous he is not merely the mouthpiece of other persons or forces" as distinct from the degree to which one exhibits authenticity); MARK D. White, THE MANIPUlation of ChOICE: ETHICS AND LIBERTARIAN PATERNALISM 84 (2013) (discussing John Stuart Mill's anti-paternalism as based on autonomy in the sense of "the right to determine one's own interests and actions."); R.S. Downie \& Elizabeth Telfer, Autonomy, 46 PHIL. 293, 293 (1971) ("An agent is sometimes said to be autonomous in virtue of his capacity to choose what to do, whether he will do X or refrain."); Marina Oshana, How Much Should We Value Autonomy?, 20 Soc. PHIL. \& PoL'y 99, 100 (2003) (understanding personal autonomy as "the condition of being self-directed, of having authority over one's choices and actions whenever these are significant to the direction of one's life."); Robert Young, Autonomy and the 'Inner Self', 17 AM. PHIL. Q. 35, 35 (1980) (distinguishing autonomy from a mindless, imitative adoption of the opinions and values of others that reflects freedom, but not autonomy in the sense necessary for genuine agency, real responsibility, and fundamental dignity); Thomas Hurka, Why Value Autonomy?, 13 Soc. THEORY \& PRAC. 361,361 (1987) ("To be autonomous, on at least one understanding, is to direct oneself where different directions are possible."); see also Richard H. Fallon, Two Senses of Autonomy, 46 STAN. L. REV. 875, 875 (1994) (discussing autonomy in the First Amendment context). 
less central to much of our most important constitutional jurisprudence. ${ }^{86}$ Given the overall variety of meanings of both paternalism and autonomy, it is not surprising that there is some uncertainty as to the relationships in legal practice between paternalism and autonomy. ${ }^{87}$ But as a first approximation, paternalism and autonomy have been thought to commonly conflict in ways classically noted by Wilhelm von Humboldt, ${ }^{88}$ John Stuart Mill, ${ }^{89}$ and by contemporary writers. ${ }^{90}$ Crucially, the significance we attach to any relationship between paternalism and autonomy will depend not only on context, but on whether we believe that autonomy in the fullest sense is at stake, or only autonomy in some less ambitious sense. Adopting the idea of autonomy in the fullest sense, as developed by writers such

86 See, e.g., Obergefell v. Hodges, 135 S. Ct. 2584, 2597 (2015) (extending fundamental constitutional liberties "to certain personal choices central to individual dignity and autonomy, including intimate choices that define personal identity and beliefs."); Lawrence v. Texas, 539 U.S. 558, 562 (2003) ("Liberty presumes an autonomy of self that includes freedom of thought, belief, expression, and certain intimate conduct."); Planned Parenthood v. Casey, 505 U.S. 833, 851 (1992) (describing "choices central to personal dignity and autonomy" as "central to the liberty protected by the Fourteenth Amendment.").

87 At least since the time of Rousseau, some have wondered whether someone can be forced to be free, or autonomous. See, e.g., JEAN-JACQUES Roussead, THE Social Contract or PrinciPles of Political Right 113 (Henry J. Trozer trans., Swan Sonnenschein \& Co. 1895) (1762); Neil Levy, Forced to be Free? Increasing Patient Autonomy by Constraining It, 40 J. MED. ETHICS 293, 300 (2014). Some have argued that certain instances of paternalism may respect, or enhance and increase, autonomy overall. See, e.g., Levy, supra, at 298-300; Cass R. Sunstein, Nudging and Choice Architecture: Ethical Considerations, YALE J. REG. (forthcoming) [hereinafter Nudging]; Cass R. Sunstein, Requiring Active Choosing is a Form of Paternalism, HARV. JoHn M. Olin Discussion PAPER SERIES, available at http:/www.law.harvard.edu/programs/olin_center/papers/782_Sunstein.php [hereinafter Requiring Active Choosing]; Donald VanDeVeer, Autonomy Respecting Paternalism, 6 SOC. THEORY \& PRAC. 187, 199-204 (1980); Martin Binder \& Leonhard K. Lades, Autonomy-Enhancing Paternalism, 68 KYKLOS 3, 3-4 (2015).

88 See Wilhelm von Humboldt, The Limits of State Action 11-15 (J.W. Burrow ed., Cambridge Univ. Press 1969) (1852).

89 See John Stuart Mill, On LiberTy 129 (Michael B. Mathias ed., Pearson Educ. Inc. 2007) (1859).

90 See Sneddon, supra note 85, at 119 ("Autonomy is at the root of the moral problem of paternalism"); Dan W. Brock, Paternalism and Autonomy, 98 ETHICS 550,550 (1988) ("[T]here has been substantial interest in the conflict between autonomy and paternalism ...."); Danny Scoccia, Paternalism and Respect for Autonomy, 100 Ethics 318, 318 (1990) [hereinafter Scoccia, Paternalism]. 
as Immanuel Kant, ${ }^{91}$ may well lead some persons to endorse a basic principle directly limiting or even precluding paternalism in a broad range of cases. Autonomy in a lesser sense that is typically focused on particular favored and disfavored causes of action and barriers to action, however, tends to neither support nor oppose paternalism as a matter of principle. Autonomy in this lesser sense tends to appear only as one consideration among others in discussions of the proper role of paternalism.

The claim that autonomy in the fullest, Kantian sense is real and viable and is often at stake in typical cases has recently come under attack. ${ }^{92}$ As we see immediately below, it is increasingly thought that anything like full Kantian autonomy depends upon unsupported metaphysical claims and bad science. ${ }^{93}$ Given this erosion of belief in full Kantian autonomy, we should expect the idea of autonomy to gradually play a more limited role in discussion of legal paternalism, rather than a role at the level of broad principle. These trends are illustrated in Section III below.

II. KaNTIAN Full AutONOMY, ITS CONTEMPORARY CRITICS, AND THE ECLIPSE OF AUTONOMY AS A FUNDAMENTAL PRINCIPLE

Immanuel Kant was not the first writer to emphasize human autonomy in a robust sense, or to link autonomy to the most fundamental sense of human dignity. ${ }^{94}$ Kant's discussion of autonomy serves well, however, in illustrating how our understanding of autonomy is today becoming increasingly diluted and less deeply meaningful. In particular, Kant famously holds that

[w]ill is a kind of causality belonging to living beings so far as they are rational. Freedom [or autonomy] would then be the property this causality [of reason] has of being able to work independently of determination by alien [or any physical or biological] causes;

91 See infra Section III.

92 See id.

93 See generally id.

94 See, e.g., Giovanni Pico della Mirandola, On the Dignity of Man 5 (Charles Glenn Wallis et al. trans., Bobbs-Merrill Co., Inc. 1965) (1486) (describing a person as his own "maker and molder" and as able to "have that which he chooses and to be that which he wills"). 
just as natural necessity is a property characterizing the causality of all non-rational beings ... ${ }^{95}$

Autonomy is in turn crucially "the ground of the dignity of human nature" $" 96$ in the most fundamental sense in which dignity is relevant to questions of paternalism. ${ }^{97}$ The exercise of Kantian autonomy, the ground of fundamental dignity, is thus incompatible with decision making that results from any combination of randomness and natural or physical causation. ${ }^{98}$

95 Immanuel Kant, Groundwork of the Metaphysic of Morals 114 (H.J. Paton trans., Harper \& Row, Publishers, Inc. 1964) (emphasis omitted) [hereinafter KANT, GROUNDWORK]; see also id. ("What else then can freedom of will be but autonomy-that is, the property which will has of being a law to itself?"); see also id. at 116 ("Reason must look upon itself as the author of its own principles independently of alien [including biological] influences.").

96 Id. at 103; see also PAUl GUYER, KANT ON FreEdom, LAw, AND HAPPINESS 97 (2000) (quoting Kant).

97 See, e.g., Barbara Herman, The Practice of Moral Judgment 203 (1993) ("The 'worth beyond price [or dignity]' of the Kantian agent is in her autonomous will."); ThOMas E. Hill, JR., DIGNITY AND PRACTICAL REASON IN KANT'S MORAL THEORY 178 (1992) [hereinafter HILl, DigNITY AND PRACTICAL REASON] ("The dignity which Kant ascribes to all persons as 'ends in themselves' is said to be grounded in their autonomy of will ...."); see also GUYER, supra note 96 , at 9 (stating that, for Kant, "autonomy has a dignity that is incomparable to the value we place on any particular object of desire ...."); Thomas May, The Concept of Autonomy, 31 AM. PHIL. Q. 133, 133 (1994) ("Since .. Immanuel Kant, autonomy has become nearly synonymous with human dignity and an imminent value in any system which purports to take seriously respect for persons.").

98 For discussion, see Christine M. KORSGAARD, CREATING THE KINGDOM OF ENDS 25 (1996) ("The will is the causality of a rational being. If the will's . . decisions are determined by the laws of nature, it is not a free [or autonomous] will."); Thomas E. HiLl, JR., AUtonOMY AND SELF-RESPECT 29 (1991) [hereinafter HiLl, AUTONOMY AND SELF-RESPECT] ("To have a will is to be able to cause events in accord with principles .... To have autonomy it is also necessary that one's will be free in a negative sense. This implies that one is capable of causing events without being causally determined to do so.") (emphasis omitted). Free will and autonomy for Kant thus require that the will be able "to act in complete independence of any prior or concurrent causes other than our own will or practical reasoning . . . " Roger J. Sullivan, Immanuel Kant's Moral TheORY 46 (1989); see also ONORA O'NeIll, CONSTRUCTIONS OF REASON: EXPLORATIONS of Kant's Practical Philosophy 52 (1989); Candace Cummins Gauthier, Philosophical Foundations of Respect for Autonomy, 3 KENNEDY InST. OF ETHICS J. 21, 23 (1993); Paul Guyer, Kant on the Theory and Practice of Autonomy, in Autonomy 70, 76 (Ellen Frankel Paul et al. eds., 2003); Thomas E. Hill, Jr., 
Typically, but not exclusively, ${ }^{99}$ of late, the credibility of this robust Kantian sense of autonomy has been called into serious question, or indeed decisively rejected. ${ }^{100}$ An important element of this trend toward abandoning full Kantian autonomy has been the increasing popularity, particularly among scientists and philosophers of science, of one version or another of what we might call physicalism or materialism. ${ }^{101}$ Materialism in this sense maintains that while there may seem to be non-material or non-physical things such as conscious minds, continuing selves, thoughts, relationships, loves, morals, and psychologies, everything is in reality either physical or inescapably dictated by the physical. ${ }^{102}$

Our concern herein is of course not with the truth or falsity of materialism or any related doctrine, ${ }^{103}$ but with one effect of the gradually increasing prominence of materialism. Thus, leading philosopher Thomas Nagel reports that "among the scientists and philosophers who ... express views about the natural order as a whole,

Kantian Autonomy and Contemporary Ideas of Autonomy, in KANT ON MORAL Autonomy 15, 20 (Oliver Sensen ed., 2013).

99 See, e.g., Juliën Offray de la Mettrie, Man a Machine, in The PorTable ENLIGHTENMENT READER 202, 203 (Isaac Kramnick ed., 1995) (1747) ("Man is . . . a complicated machine ...."). See also id. at 208. At roughly the same time, Baron d'Holbach endorsed a similar materialism. See Michael LeBuffe, PaulHenri Thiry (Baron) d'Holbach, STAN. ENCYClopedia OF PHIL. Section 2, http://plato.stanford.edu/entries/holbach (last updated Oct. 22, 2014) ("Holbach takes nature to consist in matter and motion and nothing else.").

100 See infra notes 101-03, 108-16.

101 For clarification, see, e.g., Daniel Stoljar, Physicalism, STAN. ENCYCLOPEDIA OF PHIL. Section 1, http://plato.stanford.edu/entries/physicalism (last updated Mar. 9, 2015) ("“[M]aterialism' and 'physicalism' are now often interpreted as interchangeable.").

102 See id.; See also William Jaworski, Why Materialism Is False, and Why It Has Nothing to Do with the Mind, 91 PHIL. 183, 183 (2016) ("Materialism claims that everything is physical; everything can be exhaustively described and explained in principle by physics."); Jesse M. Mulder, $A$ Vital Challenge to Materialism, 91 PHIL. 153, 153 (2016) ("One way to think of the problem of consciousness is via the question of how consciousness could just be a process like digestion ....") (quoting Josh Weisberg, ConsciousnESS 13 (2014)).

103 See, e.g., B.F. Skinner, BEYOND FreEdom AND Dignity 25 (1971) (discussing the denial of autonomy). 
reductive materialism is widely assumed to be the only serious possibility." 104 At a somewhat more specific level, philosopher Mary Midgley has referred to "the current tendency of many well-qualified scholars to claim . . . that they believe themselves ... not to exist, selves having been apparently replaced by arrangements of brain cells." 105

To what the former supposedly autonomous Kantian person is thought to reduce actually varies. If not to the above "arrangements of brain cells,"106 then perhaps to "enormously complicated biochemical machines,"107 "physical blobs,"108 "chemical scum,"109 "a bag of chemicals," "110 "a vast assembly of nerve cells and their associated molecules,"111 "complex biological machines,"112 or to a multiplicity of "mindless robots." 113

If we are ultimately reducible to any of these entities, or to any combination thereof, one implication is that autonomy in anything like the robust Kantian sense becomes unattainable and indeed

104 Thomas Nagel, Mind and Cosmos: Why the Materialist NeODARWINIAN CONCEPTION OF NATURE IS AlMOST CERTAINLY FALSE 4 (2012) (citing STEVEN WEINBERG, DREAMS OF A FinAL THEORY 51-64 (1992)).

105 Mary Midgley, Are You An Illusion? vii (2014). For an enthusiastic endorsement of this view, see Susan Blackmore, Living Without Free Will, in EXPLORING THE ILLUSION OF FREE WILL AND MORAL RESPONSIBILITY 161, 16163 (Gregg D. Caruso ed., 2013).

106 MIDGLEY, supra note 105, at vii.

107 Stephen M. Barr, Is the Human Mind Reducible to Physics? 1-2 (Lumen Christi Inst., Apr. 2015), http://www.lumenchristi.org/wp/wp-content/uploads /2015/04/Is-the-Human-Mind-Reducible-to-Physics.pdf (last visited Apr. 28, 2016).

108 Valerie Tiberius, Moral Psychology: A CONTEMPorary INTROdUCTION 16 (2015) (ebook).

109 David Deutsch, The Fabric of Reality: The Science of Parallel UnIVERSES-AND ITs IMPLiCATIONs 177-78 (1997) (quoting Professor Stephen Hawking); PAUl DAVIES, CoSMIC JACKPOT: WHY OUR UNIVERSE IS JUST RIgHT FOR LIFE 222 (2007) (same).

110 Anthony R. Cashmore, The Lucretian Swerve: The Biological Basis of Human Behavior and the Criminal Justice System, 107 Proc. NAT'L ACAD. SCI. U.S. 4499, 4504 (2010), www.pnas.org/cgi/doi/10.1073/pnas.0915161107.

111 Francis Crick, THE Astonishing HyPOTHESIS: THE SCIENTIFIC SEARCH FOR THE SOUL 3 (1994).

112 Joshua D. Greene, Social Neuroscience and the Soul's Last Stand, in SOCIAL NeURosCIENCE: TOWARD UNDERSTANDING THE UNDERPINNINGS OF THE SOCIAL Mind 263, 264 (Alexander Todorov et al. eds., 2011).

113 DAniel C. Dennett, Freedom Evolves 2 (2003). 
meaningless. As the contemporary physicist Carlo Rovelli asks, "what does it mean, our being free to make decisions, if our behavior does nothing but follow the predetermined laws of nature?"114

One answer to Professor Rovelli's question is to concede that such a view indeed lets the air out of the balloon of free will, robust autonomy, and other typically valued capacities. ${ }^{115}$ Another is to try to draw a meaningful line between causes that are operating outside and inside the cranium, with only the latter somehow offering the possibility of freedom. ${ }^{116}$ Yet another is, in full accordance with the laws of nature, to endorse some of our desires and not others, in accordance with an ordering or hierarchy of desires somehow naturally arrived at. ${ }^{117}$

Finally, one could set aside any interest in autonomy in a Kantian sense, and reduce the idea of autonomy to the level of society and politics. ${ }^{118}$ Some natural, materialist causes of our choices and behavior could then be largely taken for granted, while some other such causes, deemed to be within the broad realm of politics, could be judged to promote, respect, undermine, or violate our autonomy,

114 Carlo Rovelli, Seven Brief Lessons on Physics 72 (Simon Carnell \& Eric Segre trans., 2016) (1956). The philosopher Galen Strawson concludes, "[f] or however self-consciously aware we are as we deliberate and reason, every act and operation of our minds happens as it does as a result of features for which we are ultimately in no way responsible." Galen Strawson, The Impossibility of Ultimate Responsibility?, in EXPLORING THE ILLUSION OF FREE WILL AND MORAL RESPONSIBILITY 41, 51 (Gregg D. Caruso, ed., 2013).

115 See Alex Rosenberg, Disenchanted Naturalism, in CONTEMPORARY Philosophical NATURALISM AND ITS IMPLiCATIONS 17, 17 (Bana Bashour \& Hans D. Muller eds., 2014).

116 See RoVELLI, supra note 114, at 71.

117 See Harry G. Frankfurt, The Importance of What We Care About: PHILOSOPHICAL ESSAYS 12 (1988) ("No animal other than man, however, appears to have the capacity for reflective self-evaluation that is manifested in the formation of second-order desires."). For one neuroscientific response, see Gidon Felsen \& Peter B. Reiner, How the Neuroscience of Decision Making Informs Our Conception of Autonomy, 2 AJOB NeURoscienCE 3, 6 (2011) (discussing a possible "regress problem" in creating a "hierarchy of desires"). For another "hierarchy" approach to autonomy, see DWORKIn, ThE THEORY AND PRACTICE OF AUTONOMY, supra note 85, at 108 ("I am defining autonomy as the capacity to reflect upon one's motivational structure and to make changes in that structure.").

118 See Veljko Dubljevic, Autonomy in Neuroethics: Political and Not Metaphysical, 4 AJOB NEUROSCIENCE 44, 44 (2013) (echoing the shift in John Rawls's interest from metaphysical to political accounts of justice). 
in whatever sense of the idea of autonomy remained. ${ }^{119}$ The idea of autonomy would thus refer not to, say, the absence of barriers and constraints on choosing in general, but to the absence of some or all barriers and constraints that we somehow think of as social or broadly political. ${ }^{120}$

For our purposes, however, the key point is that if we abandon reliance on the full Kantian sense of autonomy, we should expect that the sacrifices and tradeoffs we are willing to make on matters of legal paternalism and autonomy will eventually be affected. We can certainly define ideas such as autonomy, freedom, and dignity as we wish. But on some definitions, it eventually becomes unclear why we should be willing to pay any substantial price to uphold autonomy as thus understood. At some point, autonomy in a diluted, non-Kantian sense is no longer able to draw upon the argumentative logic, depth, and weight of its Kantian ancestor. ${ }^{121}$ And at that point, debates over paternalism are steered not by accepting or rejecting autonomy as a basic principle, but by a variable mix of contextual and other non-basic considerations, with a diluted conception of autonomy appearing merely as one among many such considerations. ${ }^{122}$

As it turns out, and as we explore below, the role of principle in debates over paternalism is also being further reduced for independent reasons. In particular, the evolving nature of an increasingly interdependent and increasingly interactive society has continually eroded any workable distinction between actions that affect the actor and consenting parties, and actions that affect unconsenting third parties. We briefly consider the continuing eclipse of any such distinction below.

119 See generally id. at 46.

120 See generally id.

121 See id. at 44.

122 Thus from a pro-paternalist standpoint, it has recently been argued that autonomy, at least as understood by the writer, is "not all that valuable; not valuable enough to offset what we lose by leaving people to their own autonomous choices." Sarah Conly, Against Autonomy: Justifying Coercive PATERNALism 1 (2013). 


\section{PATERNALISM AND THE INCREASING BLURRINESS OF THE Distinction BeTweEn SELF- AND OtHeR-REgARDING Actions}

Some distinction between actions that harm the actor and those that harm other non-consenting persons is fundamental to legal paternalism. This distinction underlies the classically expressed belief that "[t]he free man owns himself. He can damage himself with either eating or drinking; he can ruin himself with gambling. If . . . he may not, he is not a free man any more than a dog." 123 The classic attempt at this distinction is that of John Stuart Mill. ${ }^{124}$

Mill's formulations of the distinction vary throughout $\mathrm{On} \mathrm{Lib-}$ erty, ${ }^{125}$ but he recognizes at several points that any such distinction will, from a utilitarian standpoint, ${ }^{126}$ sometimes be difficult. ${ }^{127} \mathrm{We}$ will leave unresolved whether any refinements and qualifications ultimately allow us to redeem the initial difficulties of the distinc$\operatorname{tion}^{128}$ because our focus is instead on the gradually increasing difficulties of applying this crucial distinction in practice.

123 NYC C.L.A.S.H., Inc. v. N.Y. State Office of Parks, Recreation, \& Historic Preserv., 51 N.E.3d 512, 514 n.1 (N.Y. 2016) (quoting G.K. Chesterton in broadcast radio talk from June 11, 1935 regarding the smoking ban in public parks).

124 See John Gray, Mill on Liberty: A DeFEnce 90 (2d ed., 1996) ("Hence, all discussion about paternalism is logically or conceptually parasitic on the possibility of making a distinction analogous to that which Mill wishes to make between self-regarding and other-regarding actions."). Mill himself attempts such a distinction in various formulations. See, e.g., MILL, supra note 89, at 70-73.

125 See, e.g., MILL, supra note 89, at 70-73, 147-51. See also C.L. TEN, MILL ON LIBERTY 11 (1980) ("Mill readily and explicitly admits that self-regarding conduct affects others, and this admission is fatal to the traditional interpretation.").

126 See MiLL, supra note 89, at 77.

127 See id. at 151 . Mill therein seeks, apparently on a utilitarian basis, to distinguish acts that directly, versus only indirectly, affect other people, while recognizing that "whatever affects himself, may affect others through himself ...." Id. at 72. J.C. Rees attempted to clarify this distinction by interpreting Mill as focusing not so much on the general effects of one's actions on other persons, but on the effects of one's actions specifically on the interests of other persons. See J.C. Rees, A Re-Reading of Mill On Liberty, in LIMITS OF LIBERTY: STUDIES OF MilL's ON LiBERTY 87, 93 (Peter Radcliff ed., 1966).

128 A leading contemporary of Mill, Sir James Fitzjames Stephen, argued simply that Mill "assumes that some acts regard the agent only, and that some regard other people. In fact, by far the most important part of our conduct regards both ourselves and others ...." JAMES FITZJAMES STEPHEN, LIBERTY, EQUALITY, Fraternity AND Three Brief EsSAys 66 (Univ. of Chi. Press 1991) (1874). 
Particularly in the areas of health care law, health insurance and other forms of insurance, public health measures, transportation and the environment, and safety and well-being in general, our public and private systems of provision have, over time, intensified and expanded our collective dependencies. ${ }^{129}$ The idealized individualism of Thoreau ${ }^{130}$ and Emerson ${ }^{131}$ in the years prior to On Liberty have increasingly given way to a more interconnected, even if stratified, law and culture. Consider, for example, the perspective taken by Dr. Martin Luther King, Jr., "I am cognizant of the interrelatedness of all communities.... We are caught in an inescapable network of mutuality, tied in a single garment of destiny. Whatever affects one directly, affects all indirectly."132

Based on our historically evolving understanding, a person "can damage himself with either eating or drinking," 133 but the damage may then be considered as a covered pre-existing condition under the Affordable Care Act. ${ }^{134}$ Typical health insurance coverage can therefore neither be denied nor increased in price on this basis, even if the health damage in question is classified as voluntarily risked or

129 For discussion at a more fundamental level, see ALASDAIR MACINTYRE, Dependent Rational Animals: Why Human Beings Need the Virtues 8 (1999) (questioning what the proper role for individual autonomy is given our unavoidable vulnerabilities and acknowledged dependencies).

130 See Henry David Thoreau, Walden and Civil Disobedience 224 (Owen Thomas ed., W. W. Norton \& Co., Inc. 1966) (1854).

131 See Ralph Waldo Emerson, The Essay on Self-Reliance 1-3 (The Roycroft Shop 1905) (1841).

132 Letter from Martin Luther King, Jr. while in Birmingham jail to his fellow clergymen (Apr. 16, 1963), www.africa.upenn.edu/Articles_Gen/Letter-Birmingham.html.

133 NYC C.L.A.S.H., Inc. v. N.Y. State Office of Parks, Recreation, \& Historic Preserv., 51 N.E.3d 512, 514 n.1 (N.Y. 2016) (quoting G.K. Chesterton in broadcast radio talk from June 11, 1935 regarding the smoking ban in public parks).

134 See Pre-Existing Conditions, U.S. DeP'T of Health \& Human SERv., http://www.hhs.gov/healthcare/about-the-law/pre-existing-conditions/index.html (last updated Nov. 18, 2014). 
incurred. ${ }^{135}$ Whatever refinements ${ }^{136}$ of Mill's self-regarding versus other-regarding conduct distinction we adopt, the distinction becomes increasingly blurry and elusive. The increasing blurriness, contestability, and dubiousness of this line in turn diminishes the scope of applicability of any broad, fundamental principle that allows for or rejects paternalism. ${ }^{137}$

The increased blurring of any line between self- and other-regarding actions is manifested in other legal subject-matter areas as well. For example, there may once have been something of a legal consensus that the private consumption of pornography produced by and for consenting adults counted as a largely self-regarding activity, despite its harms. At this point, however, any such legal consensus is under increasing attack from various perspectives. ${ }^{138}$

Similar stories of increasingly blurry distinctions could be told about negative externalities associated with prostitution between adults, ${ }^{139}$ individual vehicle fuel emissions, ${ }^{140}$ particular quantities

135 See id.; see also Anthony N. DeMaria, The Nanny State and "Coercive Paternalism", 61 J. AM. C. OF CARDiology 2108, 2109 (2013) ("There is no question that self-induced disease is common, largely preventable, and at the very least an economic burden to society.").

136 Attempting to distinguish primary or direct and immediate effects from secondary or indirect effects may well allow persons to claim that not all of contemporary civic life falls into the category of other-regarding actions, and thus outside the category of acts subject to paternalistic restriction. But the overall distinction has, in our society, become increasingly unclear. See, e.g., Rees, supra note 127, at 92-93; see also STEPHEN, supra note 128, at 66.

137 See, e.g., STEPHEN, supra note 128, at 66.

138 See Lucy Westcott, Utah Becomes First State to Declare Pornography a Public Health Hazard, News WK. (Apr. 20, 2016 at 10:53 AM), www.newsweek.com/Utah-porn-public-health-hazard-450223; S. Con. Res. 9, 61st Utah Leg., Gen. Sess. (Utah 2016); see, e.g., Catharine A. MacKinnon, ONLY WORDS 71-110 (1996); see also Gail Dines, Is porn immoral? That doesn't matter: It's a public health crisis., WASH. POST (Apr. 8, 2016), www.washingtonpost.com/posteverything/wp/2016/04/08/is-porn-immoral. This increased blurring may be related to a blurring of the distinction between the public and the private realms.

139 For discussion, see De MARNEFFE, LiBERALISM, supra note 16, at 7, 3-11; see also Emily Bazelon, Should Prostitution Be a Crime?, N.Y. TIMES (May 5, 2016), www.nytimes.com/2016/05/08/magazine/should-prostitution-be-a-crime. html?.

140 See Alex Hern, supra note 13. 
of some sugary drinks, ${ }^{141}$ smokeless tobacco in public places, ${ }^{142}$ injuries attributable to the failure to wear motorcycle helmets, ${ }^{143}$ and non-vaccination against communicable diseases. ${ }^{144}$

In these and other contexts, appeals to any basic principles either for or against legal paternalism are thus becoming less meaningful and less credible. The various complications ${ }^{145}$ and costs of policy alternatives, including their indirect and supposedly unanticipated consequences, correspondingly begin to loom larger. ${ }^{146}$ But all of the policy complications arise in the context of the increasing lack of clarity over whether a given policy addresses self-regarding or

141 See N.Y. Statewide Coal. of Hispanic Chambers of Commerce v. N.Y.C. Dep't of Health \& Mental Hygiene, 16 N.E.3d 538, 541 (N.Y. 2014). See also Sugar tax, supra note 10 (noting that "Norway taxes chocolate and sweets while Finland and France tax sweetened drinks."). The public policy prudence of imposing a tax on presumably heart-healthy dark chocolate could be contested.

142 See Weinbaum, supra note 9.

143 See, e.g., Picou v. Gillum, 874 F.2d 1519, 1522 (11th Cir. 1989) (discussing Mill on paternalism, but noting that "the costs of this injury may be borne by the public."); Robotham v. State, 488 N.W.2d 533, 540-41 (Neb. 1992) (discussing more and less direct effects on the public interest of motorcycle helmet nonuse); Benning v. State, 641 A.2d 757, 762 (Vt. 1994) (noting that helmet non-use "imposes great costs on the public.").

144 See Jacobson v. Massachusetts, 197 U.S. 11, 39 (1905) (affirming state court's decision to allow forced vaccination of healthy adult, which was later cited in Lochner v. New York, 198 U.S. 45, 55-56 (1905) as a proper use of police powers); see also Phillips v. City of New York, 775 F.3d 538, 544 (2d Cir. 2015) (per curiam) (affirming district court's decision allowing compulsory vaccination statute to stand). For broader discussion, see generally MARK NAVIN, VALUES and Vaccine Refusal: HaRd Questions in ETHICS, EPISTEMOlogy, AND HEALTH CARE 74-77 (2016) (ebook) (noting the role of cognitive biases and distrust of experts).

145 For discussion of some such complications, broadly understood, see infra Section VI.

146 On important unintended consequences of these policies, see M. Frederic Bastiat, That Which is Seen, and That Which is Not Seen, in EsSAYS ON POLITICAL ECONOMY 60-127 (London, A.W. Bennett) (1850); Robert K. Merton, The Unanticipated Consequences of Purposive Social Action, 1 AM. SOC. REV. 894, 89495 (1936); see, e.g., Peter de Marneffe, Avoiding Paternalism, 34 PHIL. \& PUB. AFF. 68, 94 (2006) ("[T]he case for and against these [arguably paternalistic] policies in their various forms is extremely complex, both normatively and empirically.") [hereinafter de Marneffe, Avoiding Paternalism]. 
other-regarding conduct, in whatever sense of this distinction we finally choose. ${ }^{147}$

Primary among these complications is that of the roles of individual, group, and official policy-making biases and pathologies in decision-making. Questions of the proper role of legal paternalism thus increasingly incorporate considerations of the decision-making biases of persons potentially subject to legal paternalism, as well as of those who might adopt or implement ${ }^{148}$ paternalistic policies. We briefly survey several of these decision-making biases and pathologies immediately below.

\section{LEGAL PATERNALISM AND THE PATHOLOGIES OF INDIVIDUAL AND OFFICIAL DECISION-MAKING}

Whether to adopt any particular regulation involving legal paternalism increasingly incorporates a more or less careful assessment of the cognitive limitations and decision-making biases of the potentially regulated parties. ${ }^{149}$ As of 1963 , the legal philosopher $H$. L. A. Hart referred to "a general decline in the belief that individuals know their own interests best." ${ }^{150}$ Any defectiveness in individual prudential choice, however, can only be part of the story. An important complication is that decision-making competence has not only a possible growth dimension, but a comparative dimension as

147 See de Marneffe, Avoiding Paternalism, supra note 1146, at 94 (noting several areas in which supposedly paternalistic policies might be defensible on grounds of protecting minors or other unconsenting third parties).

148 For background, see JEFFrey L. PRESSMAN \& AARON Wildavsky, IMPLEMENTATION: HOW GREAT EXPECTATIONS IN WASHINGTON ARE DASHED IN OAKLAND 173-74 (U.C. Press 3d ed. 1984).

149 See Jeremy A. Blumenthal, Expert Paternalism, 64 FLA. L. REV. 721, 721 (2012). See also in the advertising regulation context, Ass'n of Nat'l Advertisers, Inc. v. Lungren, 44 F.3d 726, 734 (9th Cir. 1994) (citing Ohralik v. Ohio State Bar Ass'n, 436 U.S. 447, 465-66 (1978)).

150 H. L. A. HART, LAW, LiberTy, AND MORALity 32-33 (1963) (discussing several common impediments to optimal choice). 
well. ${ }^{151}$ Wisdom and prudence specifically in public or governmental decision making also cannot be taken for granted. ${ }^{152}$

As though anticipating Hart, Jeremy Bentham classically observed that "[i]t is a standing topic of complaint, that a man knows too little of himself. $\mathrm{Be}$ it so: but is it so certain that the legislator must know more?"153 More recently, though, it has been argued in response that "even when subject to similar biases, experts are relatively better decisionmakers than laypeople." 154 As it turns out, issues of possible growth in competence, and of the relative competencies of regulators and paternalistically regulated parties, are crucial in assessing the overall value of any paternalistic intervention. ${ }^{155}$

The systematic cognitive and other biases of decisionmakers have of late generated substantial interest. ${ }^{156}$ From the standpoint of legal paternalism, however, our increasingly detailed awareness of the importance of various decision-making biases is not entirely clear in its implications. For one thing, the various cognitive biases may impose costs not only on the individual decisionmaker, but on unconsenting third parties as well, ${ }^{157}$ such that it may no longer be appropriate to think of the regulation in question as purely paternalistic. And for another, individual and group official policymakers

151 See generally Blumenthal, supra note 149, at 757 (explaining that in order to determine the propriety of paternalistic intervention, both the individuals' and the experts' respective decision-making abilities must be evaluated and compared).

152 See, e.g., id at 733-35 (discussing the benefits of decision-making by experts with substantive knowledge, skill or authority).

153 Jeremy Bentham, The Principles of Morals and Legislation 319 (Prometheus Books 1988) (1781).

154 Blumenthal, supra note 149 , at 722 .

155 See id. at 757.

156 See Gideon Keren \& Karl H. Teigen, Yet Another Look at the Heuristics and Biases Approach, in BLACKWELL HANDBOOK OF JudGMENT AND DECISION MAKING 89, 99 (Derek J. Koehler \& Nigel Harvey eds., 2004) ("[O]ne of the more popular textbooks on judgment and decision making ... counts no less than 25 biases....").

157 See J.D. Trout, Paternalism and Cognitive Bias, 24 LAW \& PHIL. 393, 393 (2005) (the cognitive biases are "not just personally costly; they are socially costly as well."). 
may also suffer from their own structural decision-making pathologies. ${ }^{158}$

Merely as examples of the well-established catalog of decisionmaking biases, consider those involving systematic overoptimism; ${ }^{159}$ problems with unreasonably discounting future events; ${ }^{160}$ arbitrary framing effects, ${ }^{161}$ anchoring our decisions on the basis of arbitrary numbers; ${ }^{162}$ self-serving personal assessments, ${ }^{163}$ including a typical failure to recognize our own incapacities; ${ }^{164}$ a tendency to unreasonably confirm and reinforce our own prior judgments; ${ }^{165}$ and grossly overgeneralizing from random events and from small and unrepresentative samples. ${ }^{166} \mathrm{We}$ tend to focus on mental images, rather than on actual quantities and magnitudes. ${ }^{167}$ More generally,

[t]he explanatory stories that people find compelling are simple; are concrete rather than abstract; assign a larger role to talent, stupidity, and intentions than to luck; and focus on a few striking events that happened rather than on the countless events that failed to happen. ${ }^{168}$

158 See the sources cited infra notes 178-83 and accompanying text, with attention in particular to Peter H. Schuck, Why Government Fails So Often AND How IT CAN Do BeTTER 158 (2014).

159 See Trout, supra note 157 , at 393.

160 See id.

161 See id. at 396.

162 See id.

163 See $i d$; see also Jean M. Twenge \& W. Keith Campbell, The NARCISSISM EPIDEMIC: LiVING IN THE AGE OF ENTITLEMENT 42-46 (2009).

164 See Justin Kruger \& David Dunning, Unskilled and Unaware of It: How Difficulties in Recognizing One's Own Incompetence Lead to Inflated Self-Assessments, 77 J. Personality \& SOC. Psychol. 1121, 1121 (1999).

165 See Raymond S. Nickerson, Confirmation Bias: A Ubiquitous Phenomenon in Many Guises, 2 ReV. GEN. Psychol. 175, 178 (1998); THOMAS GILOVICH \& LeE Ross, The Wisest One IN THE RoOM: How You Can Benefit FROM Social Psychology's Most Powerful Insights 144 (2015).

166 See Richard E. NisbetT, Mindware: ToOls fOR SMART Thinking 12 (2015).

167 See Philip E. Tetlock \& Dan Gardner, Superforecasting: The ART AND ScIENCE OF PREDiction 234-35 (2015).

168 Daniel Kahneman, Thinking, Fast and Slow 199 (2011). For a more elaborate but still incomplete catalog, see AMOS TVERSKY \& DANIEL KAHNEMAN, 
Beyond these basically uncontroversial decision-making biases, there are more contested but arguably important manifestations of systematic irrationality at the level of individual and group decisionmaking, as in theories of false consciousness ${ }^{169}$ and of our inappropriate recourse to the various Freudian defense mechanisms. ${ }^{170}$ Consider in particular whether adult decision-making, even as to legal policy, can ever be usefully thought of in terms such as denial, repression, regression, displacement, projection, identification, reaction formation, or rationalization. ${ }^{171}$ Both private actors and governments are capable as well of varying degrees of the cognitive vices of self-delusion and self-indulgence. ${ }^{172}$

Individual and group decision-making are thus commonly riddled with irrationalities of various sorts. If the harm of such irrationalities were largely confined to the actors in question, and to consenting parties, the case for paternalism would be broadly strengthened. ${ }^{173}$ But here again, ${ }^{174}$ it is increasingly difficult to determine whether any proposed response to individual irrationality should count as a form of paternalism, or else at least as importantly as an instance of protecting unconsenting third parties.

The most crucial complication, though, is that to one degree or another, the officials charged with deciding whether to impose some form of paternalistic regulation, and with implementing that regula-

Judgment Under Uncertainty: Heuristics and Biases, in JUDGMENT UNDER UnCERTAinty: HeUristics AND Biases 3-20 (Daniel Kahneman et al. eds., 1982).

169 See, e.g., Ron Eyerman, False Consciousness and Ideology in Marxist Theory, 24 ACTA SOCIOLOGICA 43, 55 (1981).

170 See Anna Freud, The Ego and the Mechanisms of Defense 42-44 (Cecil Baines, trans., Int'l Universities Press 1966) (1936) and the updating pursued in George E. Vaillant, Ego Mechanisms of Defense: A Guide for Clinicians and Researchers 3-17 (1992) and Phebe Cramer, Protecting THE SElF: Defense Mechanisms in ACtion 7 (2006).

171 For background, see the authorities cited supra note 170.

172 For background on different kinds of cognitive vices and pathologies, see authorities cited infra notes 178-183.

173 Of course, we would even then have to factor in the harms and benefits to individual cognitive and character development over time, and to one's sense of responsibility and motivation to learn.

174 See supra Section IV. 
tion, will themselves suffer from analogous biases, or else from biases and irrationalities more specific to officials and official decision-making bodies. ${ }^{175}$

Thus, decisions about legal paternalism in practice are made and implemented at all stages by authorities who are to some degree or another subject to their own variety of systematic pathologies of decision-making. ${ }^{176}$ Those authorities may also have their own public or private agendas, potentially in conflict with whatever we might imagine to be the proper role of legal paternalism. ${ }^{177}$ Their decisions may reflect, directly or indirectly, what is known as monopoly rentseeking behavior and related pathologies. ${ }^{178}$ While conformist

175 See, e.g., Mario J. Rizzo \& Douglas Glen Whitman, Little Brother is Watching You: New Paternalism on the Slippery Slopes, 51 ARIZ. L. REV. 685, 687 (2009) [hereinafter Rizzo, Little Brother is Watching]. For broader background, see sources cited infra notes 178-183.

176 See id.

177 See Julian Le Grand \& Bill New, Government Paternalism: Nanny State or Helpful Friend? 5 (2015); Matthew D. Adler \& Eric A. Posner, New Foundations of Cost-BenEFit Analysis 6-7 (2006) ("IA]dministrative agencies may have a multitude of bureaucratic or ideological goals other than the maximization of welfare."); Rizzo, Little Brother is Watching, supra note 175, at 686-87; Mario J. Rizzo \& Douglas Glen Whitman, The Knowledge Problem of New Paternalism, 2009 BYU L. REV. 905, 908-09 (2009) (noting the relevance of Friedrich Hayek's discussions of the difficulties involved in politically processing information held by many and widely dispersed actors); see also LOUIS Kaplow \& SteVen Shavell, Fairness Versus Welfare 412 (2002) ("[I]t often will be difficult for a government decisionmaker to know with confidence that the As of the world would in fact like something else better").

178 See Cass R. Sunstein, Nudges vs. Shoves, 127 HARV. L. REV. F. 210, 211 (2014) (stating that public officials may be improperly affected by the outside influences of organized private groups). For broad background, see EAMONN Butler, Public CHOICE: A Primer 76-77 (2012) ("Rent seeking is the attempt by particular groups to persuade governments to grant them . . . valuable monopolies or legal privilege.”). See also JAMES C. SCOTT, SEEING LiKE A STATE: How Certain Schemes to Improve the Human Condition Have Failed 19-20 (1998); ANdrei Shleifer \& Robert W. Vishny, The Grabbing Hand: Government Pathologies And Their Cures 92-93 (1998) (using as an example an official that grants private individuals a monopoly on government-produced goods in exchange for a bribe); William C. Mitchell \& RANDY T. Simmons, Beyond Politics: Markets, Welfare, and the Failure of Bureaucracy 66-70 (1994); Brian W. Hogwood \& B. Guy Peters, The Pathology of Public Policy 38-62 (1985); Gordon Tullock et Al., Government Failure: A Primer in Public Choice 9-10 (2002). 
groupthink ${ }^{179}$ or swarm-mindedness can certainly afflict private individual decision-making, ${ }^{180}$ the decision-making pathology of groupthink is most notorious in public decision-making contexts. ${ }^{181}$

The overall priorities of regulators and regulated parties may also differ and conflict in relevant ways. James Q. Wilson argues in particular that "advocates of regulation tend to believe that motives and intentions are more important than results, and that implementation problems are matters of mere detail and goodwill." 182 Regulated parties may not fully share these sensibilities. More generally, Peter Schuck has argued that "[n]onmarket failure, like market failure, is a systematic, incentives-based tendency of government policies." 183

The point is not that legally paternalistic policies are likely to be designed and implemented either consistently well or consistently poorly. Rather, individual and private group decision-making pathologies are merely the first among the expanding complications involved in properly classifying government interventions as paternalistic or non-paternalistic in the first place, and then in assessing the merits of legally paternalistic interventions. At some point, and most typically in some complex, particularized context, some comparison of the relevant pathologies and biases of individual citizens and government actors must logically be made. This multidimensional comparison would somehow have to take into account matters of comparative magnitudes, probabilities, interactive effects, possible improvement, and the passage of time.

179 "Groupthink" is an excessive form of concurrence- seeking among members of high prestige, tightly knit policy-making groups. See Paul't Hart, Irving L. Janis' Victims of Groupthink, 12 POL. PsYCHOL. 247, 247 (1991).

180 For a classic anticipation of some features of conformist-oriented groupthink in a private context, see Solomon E. Asch, Opinions and Social Pressure, 193 SCI. AM. 32, 32-34 (1955).

181 See generally Irving L. JANIS, VICTIMS OF Groupthink: A Psychological Study of Foreign-Policy Decisions and Fiascoes 138 (1972) (focusing in particular on the Cuban Missile Crisis); IRvING L. JANIS, Groupthink: Psychological Studies of Policy Decisions and Fiascoes 911 (2d ed., 1982).

182 JAMES Q. WILson, The Politics of Regulation, in The Politics of Regulation 357, 393 (James Q. Wilson ed., 1980). For background, see PRESSMAN, supra note 148, at 169-76.

183 SCHUCK, supra note 158 , at 150. 
Thus, in this respect as well, debate over the scope of legal paternalism is decreasingly a matter of basic principles, and increasingly a matter of detailed, murky, contextualized, painstaking conceptual and empirical inquiries. Below, we briefly note several important additional dimensions of the latter sorts of inevitably murky conceptual and empirical considerations.

\section{LEGAL PATERNALISM AND THE INCREASING SigNIFICANCE OF \\ COMPLEX, DeTAILED, CONTEXTUALIZED INQUIRY IN GENERAL}

John Stuart Mill's classic discussion of freedom ${ }^{184}$ and paternalism is explicitly intended to defend "one very simple principle" 185 regarding government intervention into private choices. In reality, though, as seems inevitable, Mill's account instead is widely recognized as far from simple. ${ }^{186}$

To begin with, both private actors and potential legal regulators must typically consider, to the extent that it is reasonable to do so, matters such as the probability of one or more looming harms; the gravity of those harms in one combination or another; the probability of achieving one's goals, or something akin thereto; the various sorts and magnitudes of value of achieving those goals; the possibility of growth and maturity over time in decision-making and the value thereof, if any; the effectiveness with which any relevant messages and incentives are actually communicated; the value, if any, of purely symbolic or expressive legal paternalism; any dignitary or privacy considerations in any relevant sense of these terms; regulatory program costs in financial terms; the various costs of evasion; and the availability and value of alternative, to some degree less

184 Self-defeatingly, Mill attempts to entirely set aside any concern for freedom of the will, as distinct from broadly political and social or interpersonal freedom. See MiLL, supra note 89, at 70.

$185 \mathrm{Id}$.

186 See David O. Brink, Mill's Progressive Principles 190 (2013) ("Mill's simple statement of his basic principle is vastly over-simple."); DALE E. Miller, J. S. Mill: Moral, Social and Political Thought 114 (2010) ("Mill may never be so far wrong as when he describes [his] liberty principle as 'very simple'."); Dworkin, MILL'S ON LIBERTY, supra note 18, at 61 ("This principle is neither 'one' nor 'very simple."'). 
risky or otherwise costly, means of achieving one or more of one's goals, or something roughly like them. ${ }^{187}$

All such considerations will commonly partake more of questionable, if not occasionally arbitrary, speculation than of uncontroversial or even clearly meaningful calculation. ${ }^{188}$ A would-be legal paternalist must often attempt to balance "the cognitive costs of improved decision against the costs of supplanting individual choice." 189 To the extent that we no longer consistently believe in fundamental dignity or in meaningful free will, ${ }^{190}$ the costs of ignoring or overriding individual wishes is thereby reduced. But abandoning the idea of genuinely free will does not seem to immediately reduce the emotional intensity of many of our desires and choices, or to instantly abolish all resentment of any perceived manipulation of one's choices.

Even if Kantian full autonomy is set aside, regulators must consider the degree to which a person's preference, choice, or action should still count as free, voluntary, or autonomous, however we might choose to define the latter terms, which are inevitably multidimensional and multifactorial. ${ }^{191}$ A further monumental complication is that on most current understandings of even thin, diluted forms of autonomy, it is entirely possible that some paternalistic interventions will respect or even increase autonomy in some regards, while violating or decreasing autonomy in other regards, or in other persons. ${ }^{192}$ We can hardly think of paternalism and autonomy as opposed basic principles if paternalism often enhances autonomy, in the regulated party and in other persons. As in the case of the literal paternalistic constraint of minor children, paternalistic regulation of

187 This typology is inspired by Feinberg, Legal Paternalism, supra note 54, at $109-10$.

188 For discussion, see Cass R. Sunstein, The Real World of Cost-Benefit Analysis: Thirty-Six Questions (and Almost as Many Answers), 114 Colum. L. REV. 167, 168-71 (2014).

189 Jeffrey J. Rachlinski, The Uncertain Psychological Case for Paternalism, 97 Nw. UnIV. L. REV. 1165, 1168 (2003).

190 See supra Section III.

191 See Feinberg, Legal Paternalism, supra note 54, at 110-11 (listing multiple requirements of full voluntariness of action).

192 See, e.g., BRINK, supra note 186, at 190-91 (Mill's prohibition on autonomously selling oneself into perpetual slavery as intended to be an autonomy-enhancing form of paternalism); Trout, supra note 157, at 414 ("Debiasing promotes rather than undermines autonomy."). See generally supra Section II. 
adult choice-making may result in both suppressing and promoting relevant competencies over the long term. ${ }^{193}$

In addition, policymakers might well consider whether adopting paternalistic policies could lead, unintentionally, to a gradual widespread desensitization to some paternalistic practices that we now typically consider objectionable. The question of the existence of genuinely slippery slopes is itself multidimensional and largely contextual. It is not unimaginable that less than fully successful paternalistic interventions may often be replaced by a succession of increasingly restrictive interventions. ${ }^{194}$ Such possibilities-as well as that of an eventual over-reactive backlash - amount to a further important, but complex, complication well beyond the realm of any basic principles.

Perhaps most important, though, are the complications that arise when we try to limit paternalism to promoting merely what the regulated party already genuinely seeks or values. The idea is roughly that such forms of paternalism can assist the regulated party in fulfilling that person's own pre-existing aims, if not their currently chosen means, and are likely to promote both autonomy and happiness. ${ }^{195}$ There will indeed be some clear and unequivocal such cases, as when we forcibly prevent someone from casually wandering off a cliff, earning their immediate gratitude and ratification. ${ }^{196}$

But in other cases, determining what someone really seeks or values, even if we consider their verbally expressed preferences, will involve monumental complications. ${ }^{197}$ The key consideration is

193 Paternalistic interventions into the behavior of reasonably competent adults may or may not be ratified at some later point by the regulated party. See generally Dworkin, MILL's ON LIBERTY, supra note 18, at 74-75.

194 For discussion from a range of viewpoints, consider the contributions of Professors Whitman, Thaler, Klick, and Frederick to the symposium entitled Slippery Slopes and the New Paternalism, CATO UnBound (April 2010), http://www.cato-unbound.org/issues/april-2010/slippery-slopes-new-paternalism (last visited May 10, 2016).

195 This confluence is typically sought especially by libertarian paternalists. For discussion, see generally Cass R. Sunstein, Why Nudge?: The Politics of LIBERTARIAN PATERNALISM 129 (2014). Libertarian paternalism is exemplified by the required disclosure of food calorie counts in the absence of further manipulation, penalty, reward, distraction, burden, or constraint. See One-Year Countdown to Calorie Counts, supra note 11.

196 See, e.g., Feinberg, Legal Paternalism, supra note 54, at 112.

197 See, e.g., id. at 114-116. 
not that our individual goals may not actually be promoted by the means we choose to pursue those goals. ${ }^{198}$ Even in such cases, we sometimes ascribe intrinsic value to a chosen means, or to our ability to grow through making the choice, thereby blurring the distinction between means and ends. ${ }^{199}$ Sometimes, the means we choose in seeking an end is itself of great value to us. ${ }^{200}$

Rather, the crucial complication is that each of us genuinely seeks incompatible important goals. The idea that each individual values or pursues mutually inconsistent goals, often at a single given time, underlies some of our great literature, as well as arguments of many of the great humanists and philosophers. ${ }^{201}$ Legal paternalists thus cannot claim to promote one of those goals, at the expense of another, by relying solely on our own clear preferences. Instead, paternalists must adopt some other rationale for privileging any one of our important goals at the expense of others; or so, at least, one could reasonably argue, thus creating a further crucial and typically contextualized complication. ${ }^{202}$

198 See, e.g., Marina Oshana, Against Autonomy: Justifying Coercive Paternalism, 124 ETHICS 392, 396 (2014) (reviewing SARAH CONLY, AGAINST Autonomy: Justifying COERCIVE PATERnAlism (2012)). This would amount to only the simplest sort of self-defeating behavior. See id.

199 See id. at 395-96.

200 See id. at 395.

201 At the absolute extreme, consider Robert LOUIS StEVEnSON, STRANGE CASE OF DR. JEKYLL AND Mr. HydE (Richard Dury ed., 2004) (1886). More manageably, suppose that a paternalist wanted to promote Hamlet's values, or the values the paternalist thought Hamlet ought to have. Let us here simply assume that Hamlet knows, consciously, his own goals. Could the paternalist really construct some sort of neutrally explained, fully consistent hierarchy of Hamlet's relevant values? If we think so, we must confront a range of issues briefly referred to above, as raised by Rousseau, Marx, Sigmund and Anna Freud, and a plethora of others. See RouSSEAU, supra note 87 at 113 and accompanying text; Eyerman, supra note 169 at 43; FREUD, supra note 170 at 5-10. For background, see ISAIAH BERLIN, LIBERTY: INCORPORATING FOUR ESSAYS ON LIBERTY 166-181 (Henry Hardy ed., 2002).

202 To layer on a further, undeniably important complication thereon, consider RONALD DwORKIN, TAKING RIGHTS SERIOUSLY 234 (1977), in which Professor Dworkin discusses the status of "external preferences." We might, for example, prefer some level of income or wealth for ourselves, while also holding a more or less sustained, intense, or somehow "deeper" preference for how income and wealth should be distributed at a broad societal level. Can a paternalist readily determine how a person really prioritizes these two kinds of preferences? 
And finally, there are the various more specific complications more or less uniquely associated with each of the distinct subject matter areas that often involve legal paternalism. Merely for example, consider the arguably paternalistic ${ }^{203}$ legal regulation of recreational or mood-altering drugs. ${ }^{204}$ No basic abstract principle can allow us, for example, to predict how much legalization - or some form of decriminalization - of one or more such drugs will increase or decrease the consumption of any particular drug, or any associated social costs. ${ }^{205}$

More specifically, no basic principle of either support for or rejection of legal paternalism can even begin to clarify the price elasticity of demand, under various circumstances, for a particular drug; the status of a drug as what is technically known as an inferior or superior economic good; the degree of competitiveness of future supply markets for the drug; the effects on any related crimes of fraud or violence; possible regimes of sales and excise taxes; the collection, and any systematic evasion, of such taxes; the real value of any purposes to which such additional tax revenues are put; the costs and benefits of any legally mandated strengths or quality control measures and the evasion of such regulations; issues of civil or criminal liability for breaches of regulations associated with decriminalization; any increased costs of rent-seeking efforts in the context of drug deregulation; interstate smuggling under different legal and tax regimes; the possibility of a net reduction in the costs of prosecuting drug related activities; and any effects, over time, on rates of impaired driving, and of drug addiction and costs of treatment. ${ }^{206}$

Individually and cumulatively, these considerations are neither trivial nor obvious in their impact, let alone in their magnitude or moral weight. Increasingly, responsible discussion of anti-paternalistic drug decriminalization will inevitably focus on our best

203 As implied by Section IV, mood-altering drugs could be regulated entirely on either paternalistic or non-paternalistic grounds, or on a mixture thereof.

204 A further complication is that we might want to vary the degree of paternalism according not only to the particular drug, but to the particular circumstances of use as well.

205 For background, see HUSAK \& DE MARNEFFE, supra note 3, at 101.

206 See generally id. at 100; Ranjit Dighe, Legalize It-The Economic Argument, HufFington Post (Jan. 30, 2014), http://www.huffingtonpost.com/ranjitdighe/legalize-marijuana-economic-argument_b_4695023.html (last updated Ap ril 1, 2014). 
guesses, slowly accumulating experiences, and on detailed, technical arguments as to the above sorts of considerations, rather than on the more or less mechanical application of any broad paternalist or anti-paternalist principles.

\section{The ECLIPSE OF PRINCIPLE IN THE GLUCKSBERG Assisted SUICIDE CASE}

Each of the basic themes explored above can be illustrated in the evolving national and international debate over arguably paternalistic restrictions on the legal availability of assisted suicide. The number of thoughtful discussions regarding the law and morality of assisted suicide and of voluntary euthanasia is quite substantial, ${ }^{207}$ with concerns for paternalism and autonomy often being central thereto. ${ }^{208}$ In some instances, paternalism may underlie not only the

207 For a brief overview, see generally Robert Young, Voluntary Euthanasia, STAN. ENCYCLOPEDIA OF PHIL., http://plato.stanford.edu/entries/euthanasia-voluntary (last updated Dec. 16, 2014); Dan W. Brock, A Critique of Three Objections to Physician-Assisted Suicide, 109 ETHICs 519, 521-23 (1999); John Deigh, Physician-Assisted Suicide and Voluntary Euthanasia: Some Relevant Differences, 88 J. CRIM. L. \& CRIMINOLOGY 1155, 1156 (1998); Luke Gormally, Euthanasia and Assisted Suicide: Seven Reasons Why They Should Not Be Legalized, CATHOLIC NEws AGENCY, http:/www.catholicnewsagency.com/resources/lifeand-family/euthanasia-and-assisted-suicide/euthanasia-and-assisted-suicideseven-reasons-why-they-should-not-be-legalized/ (last visited May 12, 2016); Danny Scoccia, Physician-Assisted Suicide, Disability, and Paternalism, 36 Soc. THEORY \& Prac. 479, 481 (2010); Alan Soble, Paternalism, Liberal Theory, and Suicide, 12 CAN. J. PHIL. 335, 335 (1982); Bonnie Steinbock, The Case for Physician Assisted Suicide: Not (Yet) Proven, 31 J. Med. ETHICs 235, 235 (2005); Judith Jarvis Thomson, Physician-Assisted Suicide: Two Moral Arguments, 109 ETHICs 497, 497 (1999); Carl Wellman, A Legal Right to Physician-Assisted Suicide Defended, 29 Soc. TheOry \& Prac. 19, 22 (2003); Carl Wellman, A Moral Right to Physician-Assisted Suicide, 38 AM. PHIL. Q. 271, 271 (2001). For broader discussion of the appropriate role of medical paternalism, see TOM L. BeAuchamp \& James F. ChILdRESS, PRINCIPLES OF BiomedicAl ETHICS 101-41 (7th ed. 2013) (on autonomy); see also Allen Buchanan, Medical Paternalism, 7 PHIL. \& Pub. AfF. 370 (1978).

208 See generally the authorities cited supra note 207. See also Gerald Dworkin, Introduction to EUTHANASIA AND ASSISTED SUICIDE 5 (Gerald Dworkin, R.G. Frey \& Sissela Bok eds., 1998) (endorsing "the claims of autonomy and relief of suffering of competent patients who are suffering from a terminal illness or an intractable, incurable medical condition that the patient experiences as incompatible with her fundamental values"). 
legally binding rules and the judgments of hospitals and physicians, but the private decisions of families ${ }^{209}$ and even of the patients themselves. ${ }^{210}$ The family of a person contemplating assisted suicide may thus seek to paternalistically override the admittedly competently arrived at preferences of that person. ${ }^{211}$ And a person might choose for or against assisted suicide based partly on the perhaps paternalistic belief that the family does not recognize or cannot promote its own long-term interests. ${ }^{212}$ Again, our purpose herein is not to take sides on any normative issue, but to emphasize the diminishing value in our day of broadly principled stances for or against legal paternalism.

To the extent that suicide, and assisted suicide in particular, affect non-consenting third parties, the most valuable debate must focus in part on boundary line questions, along with various other particularized and contextualized questions. ${ }^{213}$ As suggested above, some assisted suicide cases will involve mixtures of several distinct motives. ${ }^{214}$ Such motives may include a desire to shape, to some degree, the basic structure of one's life, ${ }^{215}$ a possible sense of pointlessness, alienation, futility, moral obligation, responsibility, social benevolence, nihilism, isolation, hopelessness, or anomie; a concern for dignity in the sense of an anticipated, or feared, personally, or socially, perceived humiliation; a deep cultural or religious commitment to a morality of honor and disgrace, or of personal independence, ${ }^{216}$ one's metaphysical commitments and attitudes toward pain or suffering; and a desire to promote the interests of one's family.

209 See Felicia Ackerman, Assisted Suicide, Terminal Illness, Severe Disability, and the Double Standard, in Physician Assisted SUICIDE: ExPANDING THE DeBATE 149, 157 (Margaret P. Battin, Rosamond Rhodes \& Anita Silvers eds., 1998).

210 See id.

211 See id.

212 See id.

213 See supra Section IV.

214 See Ackerman, supra note 209, at 150-58.

215 See, e.g., Ronald Dworkin, et al., Assisted Suicide: The Philosophers' Brief, NEW YORK REVIEW OF BOOKS (Mar. 27, 1997), www.nybooks.com/articles /1997/03/27/assisted-suicide-philosophers-brief. For commentary thereon, see Paul J. Weithman, Of Assisted Suicide and "The Philosophers' Brief", 109 ETHICS 548, 549-53 (1999).

216 See MACINTYRE, supra note 129 , at 86. 
Not all such motives may justify legal paternalism to an equal degree. ${ }^{217}$

The major American case addressing physician assisted suicide is Washington v. Glucksberg. ${ }^{218}$ While it is doubtless tempting to think of the Glucksberg case as a broad showdown between advocates of a generalized constitutional right to personal autonomy ${ }^{219}$ and advocates of the federal constitutional permissibility of statelevel medical paternalism, the essence of the case is really found in the aggregate of its various lower-level, contextualized, more specific complications.

The Glucksberg Court was crucially concerned, for example, with several narrower gauge issues such as the scope and boundaries

217 The problem of a mixed-motive suicide case can overlap with the more basic question of what constitutes a genuinely suicidal decision in the first place. Immanuel Kant characterized at least some suicide cases as akin to a sentry deserting his assigned post. See ImManuel Kant, LeCtures on Ethics 148-149 (Peter Heath \& J.B. Schneewind eds., Peter Heath, trans., Cambridge Univ. Press 1997) [hereinafter KANT, LECTURES ON ETHICS]. But it would seem that remaining at one's assigned military post, in the face of certain death, for no evident military benefit, may or may not count as suicidal. See, e.g., id. at 146.

Kant elsewhere seeks to illustrate the idea of a categorical imperative through questioning whether maxims of self-love or of avoiding disutility underlying a choice of suicide could be universalized. See KANT, GROUNDWORK supra note 95, at 89 . But elsewhere, Kant seems to more broadly reject suicide grounded in the value of autonomy, on the obvious ground that autonomy-asserting suicide puts an end to the autonomous actor. See id. at 96-97; KANT, LECTURES ON ETHICS, supra, at 145 . Kant actually seems to rely, to some degree, on a sense of horror or abhorrence at the presumed unnaturalness of suicide. See id. at 146.

For further discussion of Kant on suicide, see Michael Cholbi, Kantian Paternalism and Suicide Intervention, in PATERNALISM: THEORY AND PRACTICE 115, 125 33 (Christian Coons \& Michael Weber eds., 2013); Michael J. Cholbi, Kant and the Irrationality of Suicide, 17 HIST. PHIL. Q. 159 (2000); Michael J. Seidler, Kant and the Stoics on Suicide, 44 J. HIST. IDEAS 429 (1983); Gerard Vong, In Defence of Kant's Moral Prohibition on Suicide Solely to Avoid Suffering, 34 J. MED. ETHICS 655 (2008).

218 Washington v. Glucksberg, 521 U.S. 702 (1997).

219 See Ronald Dworkin, et al., supra note 215 (understandably devoting substantial attention to such matters). See also, in the investigational drug availability context, Abigail Alliance v. Eschenbach, 495 F.3d 695, 717 (D.C. Cir. 2007) (Rogers, J., dissenting) (recognizing "the concept, fundamental in American jurisprudence, that 'every human being of adult years and sound mind has a right to determine what shall be done with his own body." (citations omitted)). 
of any legitimate state interest in preserving life. ${ }^{220}$ In this respect, the crucial dispute in this context was not over the sheer existence of any such legitimate interest, but whether such an interest, if pursued by a state, is confined to those persons who can both "contribute to society and have the potential to enjoy life," 221 whether the wishes of the patient must be considered at this point, ${ }^{222}$ or whether the state interest in promoting life can instead be more broadly construed. ${ }^{223}$ A further imaginable option would be to confine the legitimate scope of the state interest in preserving life to persons with the declared or apparent potential to subjectively enjoy life, whether that person is also judged to be in some relevant sense a potential net contributor to society or not. ${ }^{224}$

Further, the scope of any possible federal or state constitutional right to assisted suicide would also inevitably depend on narrowgauge, particularized, and partly empirical questions going to difficult matters of individual competence and consent. ${ }^{225}$ Any clinical psychological depression; ${ }^{226}$ the degree of consistency, persistence, and clarity of the desire for assisted suicide; and the understanding of likely future medical risks, options, treatments, side effects, and outcomes must be considered by the patient or an appropriate decisionmaker along with the regulating government. ${ }^{227}$

No less crucial are complex questions of the potential for subtle and even unintended forms of informal coercion related to poverty, public costs and benefits, short-term budget constraints, public relations, insurance status, age, or disability. ${ }^{228}$ Any such considerations might actually narrow the scope of any supposed right against paternalistic restrictions, lest the supposed right to assisted suicide be

\footnotetext{
220 See Glucksberg, 521 U.S. at 728-30.

221 Id. at 729 (quoting Respondents' brief).

222 See id. (citing the Ninth Circuit opinion below).

223 See id. (citing the State of Washington's official view). For a further variety of conceivably legitimate government interests in aid in dying cases, see Morris v. Brandenburg, 356 P.3d 564, 579 (N.M. Ct. App. 2015).

224 See generally Glucksberg, 521 U.S. at 729.

225 See generally id. at 729-31.

226 See id. at 730.

227 See generally id. at $730-31,733$.

228 See id. at 732.
} 
transformed into what amounts to a contextualized duty to die, or into an instrument of discrimination. ${ }^{229}$

On the other hand, a right to assisted suicide might be expanded if what is thought to constitute a "terminal" illness is thought to be often too complex or contestable. ${ }^{230} \mathrm{We}$ might then wish to err on the side of rights-protection by eliminating any requirement that the illness be terminable.

More broadly, the relevance of highly contextualized "slippery slope" arguments bearing specifically upon assisted suicide must then inevitably be somehow addressed. ${ }^{231}$ The slipperiness of any particular slope regarding, for example, an initial legal requirement that there be a terminal and not merely a chronic or acute illness, or of unrelieved suffering or physical pain, or of any physician involvement at one stage or another, would all require attention at some point. ${ }^{232}$ Even if we perceived a slippery slope toward fewer restrictions on assisted suicide in, we would have to decide whether we would still object to ending up at the bottom of the particular slippery slope by the time we actually arrived there.

Even more subtly, the various issues associated with possible professional role stress for the health professionals involved, as well as any possible fear on the part of the patient, of judgmentalism, of a bureaucratic mentality, or of shifting realistic interests and loyalties on the part of the most directly involved health care professionals, must be somehow addressed. ${ }^{233}$ It is certainly possible to argue that professional role stress in such cases will either be minimal or else largely confined merely to a transitional generation of health care professionals. Again, though, our point herein is not to take sides on any such questions, but to emphasize the increasing importance in the assisted suicide contexts of many such relatively narrow-gauge, complex, circumstantial, partly empirical issues, rather

\section{See id.}

230 See id. at 733; see also id. at 752-54 (Souter, J., concurring). Such determinations would crucially depend upon choosing some more or less arbitrary time frame, and some particular degree of tolerance for what we imagine to be any errors in prognosis. See id. See also United States v. Rutherford, 442 U.S. 544, 556-57 (1979) (regarding the statutory drug safety and efficacy requirement in the context of purportedly terminally ill patients).

231 See Glucksberg, 521 U.S. at 732-33. See also generally supra note 194.

232 See Glucksberg, 521 U.S. at 754-55 (Souter, J., concurring).

233 See id. at 731. 
than any broad principles. ${ }^{234}$ This theme recurs throughout any discussion of the proper contemporary role of legal paternalism in general.

\section{CONCLUSION}

We commonly think of debates over the proper role of legal paternalism as largely focused on issues of basic principles. This Article has, to the contrary, called attention to the developing eclipse of broad or basic principle in matters of legal paternalism.

In part, this eclipse of principle is due to the increasing variety of distinct understandings of both legal paternalism and of the idea of autonomy, to which legal paternalism increasingly bears a contested and complex relationship.

Beyond this development, there is a rapidly increasing skepticism toward the view of autonomy that would afford the most ambitious foundation for broadly rejecting paternalism at a fundamental level - that of full Kantian-style autonomy. To the extent that full

234 At the state level, see, e.g., Cal. Assemb. Bill 15, 2015-2016 2d Ex. Sess., ch. 1, 2015 (Cal. 2015) (recognizing a relatively narrowly constrained right of terminally ill persons to physician assisted suicide). See also Donorovich-O'Donnell v. Harris, 194 Cal. Rptr. 3d 579, 582-83 (2015) (holding that there is no California state constitutional right to assisted suicide despite a newly enacted, but not yet effective and potentially challengeable, state statute). Similar narrowgauge issues have been playing themselves out in Canada as well, despite any headline-oriented focus on the assertion or denial of broad constitutional rights to assisted suicide. For background, see the Canadian Supreme Court's recognition of a relatively broad but also variously constrained right to physician suicide in Carter v. Canada, [2015] 1 S.C.R 331, 335 (Can.) (recognizing, for example, the possible perverse incentive for premature personal suicide before the patient loses the ability to commit suicide without physician assistance); KELVIN KENNETH Ogilive \& Robert Oliphant, Medical Assistance in Dying: A PatientCentred Approach, 42nd Parliament, 1st Session., Rep. of the Special JoINT COMM. ON PHYSICIAN-Assisted Dying 12 (Feb. 2016), http://www.parl. gc.ca/content/hoc/Committee/421/PDAM/Reports/RP8120006/pdamrp01/pdamr p01-e.pdf (emphasizing the concept of subjective intolerability for the patient, as distinct from terminality, or any irremediability of the medical condition); Canadian Medical Association, Principles-Based Recommendations for A CANAdian APPROACH TO Assisted Dying (Jan. 2016) https://www.cma.ca/Assets/assets-library/document/en/advocacy/cma-framework_assisted-dying_finaldec-2015.pdf (similar). For further comparative perspective, see Stephen Hoffman, Euthanasia and Physician-Assisted Suicide: A Comparison of E.U. and U.S. Law, 63 SYRACUSE L. REV. 383, 389-96 (2013). 
Kantian autonomy loses credibility, the argumentative focus naturally shifts toward various narrower, more contextualized, detailed, and complex issues and claims.

As well, all forms of the classic distinction emphasized by John Stuart Mill between actions that can somehow be regarded as selfregarding, and actions that can be considered to be other-regarding, as a ground for a broadly principled approach to legal paternalism, are in our culture increasingly dubious. In various respects, persons are today more intensively interrelated and crucially interdependent, and even inseparable, than would have typically been the case in Mill's day.

We are also increasingly recognizing the crucial role of various cognitive biases, pathologies, and systematic irrationalities involved in individual decision-making. A crucial complication, though, is that we also increasingly recognize either similar or different such systematic biases in the adoption and implementation of legally paternalistic and other government policies. Remarkably multidimensional problems of comparative biases and pathologies as among private and public actors thus loom larger in discussions of legal paternalism.

Finally, this Article has gathered a number of more contextualized, but important, problems illustrating the increasing significance of various narrow-gauge, multidimensional, circumstance-based, particularized inquiries into concepts and evidence, as distinct from basic principle. A number of these trends are on display, in concrete fashion, in the context of the Glucksberg assisted suicide case. Such relatively detailed considerations, however, promise to loom increasingly large in discussions of the proper role and limits of legal paternalism in any context. 